\title{
Expression and Function of GABA Receptors in Myelinating Cells
}

\author{
Mari Paz Serrano-Regal 1,2,3†, Laura Bayón-Cordero 1,2,3, Rainald Pablo Ordaz ${ }^{4}$, \\ Edith Garay ${ }^{4}$, Agenor Limon ${ }^{5}$, Rogelio O. Arellano ${ }^{4}$, Carlos Matute ${ }^{1,2,3 *}$ and \\ María Victoria Sánchez-Gómez ${ }^{1,2,3 *}$
}

${ }^{1}$ Laboratory of Neurobiology, Achucarro Basque Center for Neuroscience, Leioa, Spain, ${ }^{2}$ Department of Neurosciences, University of the Basque Country (UPV/EHU), Leioa, Spain, ${ }^{3}$ Centro de Investigación Biomédica en Red de Enfermedades Neurodegenerativas (CIBERNED), Leioa, Spain, ${ }^{4}$ Laboratorio de Neurofisiología Celular, Instituto de Neurobiología, Universidad Nacional Autónoma de México, Juriquilla, Mexico, ${ }^{5}$ Department of Neurology, Mitchell Center for Neurodegenerative Diseases, University of Texas Medical Branch, Galveston, TX, United States

Myelin facilitates the fast transmission of nerve impulses and provides metabolic support to axons. Differentiation of oligodendrocyte progenitor cells (OPCs) and Schwann cell (SC) precursors is critical for myelination during development and myelin repair in demyelinating disorders. Myelination is tightly controlled by neuron-glia communication and requires the participation of a wide repertoire of signals, including neurotransmitters such as glutamate, ATP, adenosine, or $\gamma$-aminobutyric acid (GABA). GABA is the main inhibitory neurotransmitter in the central nervous system (CNS) and it is also present in the peripheral nervous system (PNS). The composition and function of GABA receptors (GABARs) are well studied in neurons, while their nature and role in glial cells are still incipient. Recent studies demonstrate that GABA-mediated signaling mechanisms play relevant roles in OPC and SC precursor development and function, and stand out the implication of GABARs in oligodendrocyte (OL) and SC maturation and myelination. In this review, we highlight the evidence supporting the novel role of GABA with an emphasis on the molecular identity of the receptors expressed in these glial cells and the possible signaling pathways involved in their actions. GABAergic signaling in myelinating cells may have potential implications for developing novel reparative therapies in demyelinating diseases.

Keywords: GABA, GABA receptor, oligodendrocyte, Schwann cell, differentiation, myelination

\section{INTRODUCTION}

Glial cells express a vast repertoire of receptors and transporters for neurotransmitters and neuromodulators and respond to axonal signals, being key and active elements of the nervous system (Allen and Lyons, 2018). In vertebrates, oligodendrocytes (OLs) and Schwann cells (SCs) are the myelin-forming glia of the central nervous system (CNS) and peripheral nervous system (PNS), respectively. These cells are responsible for myelin building and maintenance, a function highly regulated by neuronal activity (Gibson et al., 2014; Mitew et al., 2018). Myelin speeds up nerve impulse propagation and provides metabolic and trophic support to axons (Nave and Trapp, 2008; Kidd et al., 2013; Philips and Rothstein, 2017). Thus, myelination represents the major function of these cells, although they carry it out with some differences; while OLs can myelinate multiple axons simultaneously, each SC 
wraps one single axon (Jessen and Mirsky, 2005; Nave and Trapp, 2008). Regarding their specific characteristics, oligodendroglial cells represent a highly diverse and specialized cell population (Marques et al., 2016). Mature myelinating OLs develop from glial precursors named oligodendrocyte progenitor cells (OPCs), which constitute the main proliferating cell type in the adult CNS (Dawson et al., 2003). On the other hand, SCs derive from SC precursors, which differentiate into immature SCs. These immature SCs can generate both myelinating and non-myelinating SCs (or Remak glia) according to PNS requirements, like the presence of specific signals in the microenvironment and the diameter of axons in their vicinity (Jessen and Mirsky, 2005, 2019; Kidd et al., 2013).

Differentiation of OPCs and SC precursors is necessary for remyelination in demyelinating diseases like multiple sclerosis (MS) and myelin formation in dysmyelinating diseases such as leukodystrophies in the CNS or Charcot-Marie Tooth in the PNS. In this regard, understanding the mechanisms of action involved in this complex neuron-glia crosstalk will help us in the search for new therapeutic approaches in these pathologies.

Neuronal activity and several signals such as transcriptional and growth factors, axonal ligands, hormones, extracellular matrix components or neurotransmitters regulate OPC/SC precursor differentiation and myelination. Among them, GABAergic signaling has attracted great interest in the last years (Procacci et al., 2013; Zonouzi et al., 2015; Arellano et al., 2016; Hamilton et al., 2017; Serrano-Regal et al., 2020).

GABA, which is present both in the CNS and PNS, exerts an excitatory role during development to modulate neuronal growth and synapse formation (Ben-Ari, 2002). It acts mostly through ionotropic $\mathrm{GABA}_{\mathrm{A}}\left(\mathrm{GABA}_{\mathrm{A}} \mathrm{Rs}\right)$ and metabotropic $G_{A B A}$ receptors $\left(G A B A_{B} R s\right)$ that are well described in neurons but not yet fully characterized in myelinating cells. Although the expression of GABA receptors (GABARs) in OL/SC precursor lineages is widely documented (von Blankenfeld et al., 1991; Williamson et al., 1998; Magnaghi et al., 2004; Luyt et al., 2007; Arellano et al., 2016; Serrano-Regal et al., 2020), their role in differentiation and myelination is a matter of ongoing research.

In this review, we recapitulate recent evidence about $\mathrm{GABA}_{\mathrm{A}}$ and $\mathrm{GABA}_{\mathrm{B}}$ receptor expression and function in oligodendroglial and SCs, together with the implication of the GABAergic signaling in $\mathrm{OPC} / \mathrm{SC}$ differentiation and myelination. Furthermore, we discuss possible signaling pathways involved in these events and their relevance to develop new therapies to treat demyelinating and dysmyelinating diseases.

\section{EXPRESSION OF GABARs IN OLIGODENDROGLIAL AND SCHWANN CELLS}

\section{GABA $_{A}$ Receptors}

$\mathrm{GABA}_{\mathrm{A}} \mathrm{Rs}$ are integral membrane ion channels-permeable to $\mathrm{Cl}^{-}$and $\mathrm{HCO}_{3}{ }^{-}$anions-composed of five subunits that mediate the major form of fast inhibitory neurotransmission in the CNS (Olsen and Sieghart, 2008; Doyon et al., 2016). There are, at least, 19 distinct $\mathrm{GABA}_{\mathrm{A}} \mathrm{R}$ subunit genes, which include $6 \alpha(\alpha 1-\alpha 6), 3 \beta$ ( $31-\beta 3), 3 \gamma(\gamma 1-\gamma 3), 3 \rho$ ( $31-$ $\rho 3)$, and 1 gene of the respective $\delta, \varepsilon, \theta$, and $\pi$ subunits (Sieghart and Savić, 2018). This diversity results in different homomeric or heteromeric subunit combinations that may have specific locations in the CNS, particular pharmacology, and, consequently, distinctive functional characteristics (Vogt, 2015). The subunit profile that forms $\mathrm{GABA}_{\mathrm{A}}$ Rs depends on several factors including brain region, cell type, developmental stage, and physiological or pathophysiological conditions (Levitan et al., 1988; Seeburg et al., 1990; Waldvogel and Faull, 2015). Currently, $11 \mathrm{GABA}_{\mathrm{A}} \mathrm{R}$ subtypes with different subunit combinations have been identified, being most of them heteromeric receptors formed by $\alpha x \beta x \gamma x$ or $\alpha x \beta x \delta$ (where $x$ represents any subtype of a given subunit; Figure 1A), whereas others are homomeric receptors formed by $\rho$ subunits (Barnard et al., 1998).

\section{Oligodendroglial Cells}

Activation of $\mathrm{GABA}_{\mathrm{A}} \mathrm{Rs}$ is relevant for the modulation of myelinating cell physiology (Magnaghi, 2007; Vélez-Fort et al., 2012), however, the specific subunit composition of $\mathrm{GABA}_{\mathrm{A}} \mathrm{Rs}$ expressed in these cells remains unknown. Electrophysiological recordings in OPCs and OLs reveal differences between the response of the $\mathrm{GABA}_{\mathrm{A}} \mathrm{R}$ expressed in these cells and those expressed in neurons and astrocytes (Table 1), suggesting the presence of a novel $\mathrm{GABA}_{\mathrm{A}} \mathrm{R}$ subtype with unique stoichiometry in the oligodendroglial lineage (von Blankenfeld et al., 1991; Williamson et al., 1998; Vélez-Fort et al., 2012; Arellano et al., 2016).

von Blankenfeld et al. (1991) suggested that $\mathrm{GABA}_{\mathrm{A}} \mathrm{Rs}$ in murine OPCs and OLs carry a $\gamma$ subunit required to form the benzodiazepine binding site, as they observed potentiation of the GABA response in these cells with classic benzodiazepines. Moreover, the inverse agonist $\beta$-carboline methyl 4-ethyl-6,7dimethoxy- 9 H- $\beta$-carboline-3-carboxylate (DMCM) reduced the GABA-induced current responses in oligodendroglial cells, unlike what happens in astrocytes. Contrary to that, Williamson et al. (1998) reported no influence of flunitrazepam or DMCM in the response elicited by GABA in rat-derived OPCs, indicating an absence of the $\gamma$ subunit in the $\mathrm{GABA}_{\mathrm{A}}$ Rs expressed by these cells. This observation was supported by the inhibitory effect of $\mathrm{Zn}^{2+}$, which is characteristic of receptors that lack the $\gamma 2$ subunit. RT-PCR analyses conducted in the same study did not find expression of $\gamma 2, \alpha 1, \alpha 6$, and $\delta$ subunit mRNAs in OPCs. Although amplification of other subunits was demonstrated, the results were interpreted with caution since the preparation was $85 \%$ pure for OPCs and the presence of $\mathrm{GABA}_{\mathrm{A}}$ Rs from other cell types could not be excluded. In a third study conducted by Bronstein et al. (1998), the GABA response of an immortalized murine glial cell line that expresses mature myelin proteins was insensitive to diazepam and sensitive to $\mathrm{Zn}^{2+}$, reinforcing the idea of $\gamma$-subunit absence.

Later, Passlick et al. (2013) reported the expression of two types of $\mathrm{GABA}_{\mathrm{A}} \mathrm{Rs}$ in hippocampal NG2 cells from juvenile mice by functional and pharmacological analyses and single-cell RT-PCR. NG2 cells from this brain area express, on the one hand, postsynaptic $\mathrm{GABA}_{\mathrm{A}}$ Rs comprised of a combination of $\alpha 1, \alpha 2, \beta 3, \gamma 1$, and $\gamma 2$ subunits and, on the other hand, they 

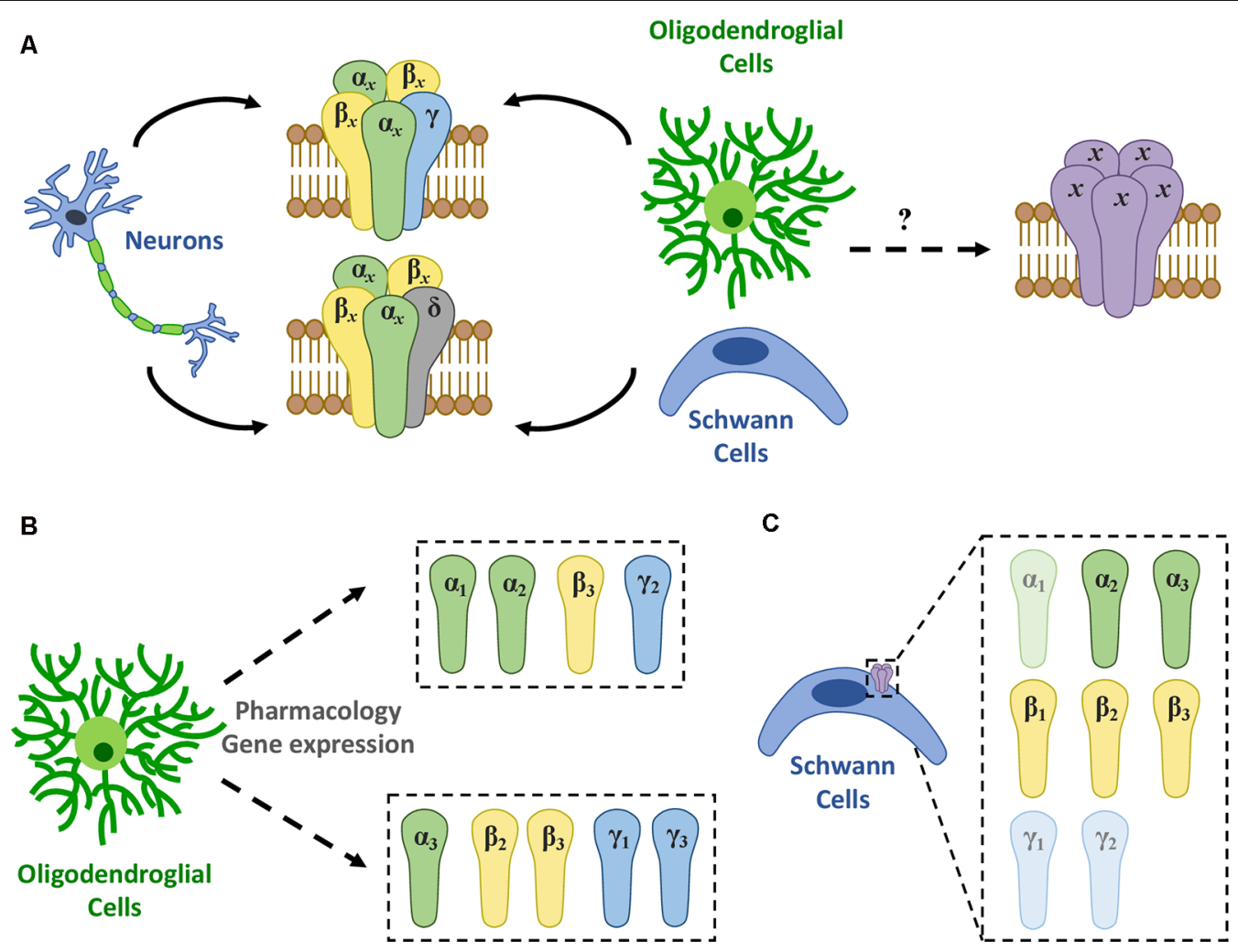

FIGURE 1 | GABA $A_{A}$ R expression in myelinating cells. (A) There are 11 different $G A B A_{A} R$ subtypes described, mainly heteromeric receptors with $\alpha \times \beta \times \gamma \times$ or $\alpha \times \beta \times \delta$ (where $x$ represents any subtype of a given subunit) stoichiometry (Olsen and Sieghart, 2008). Among them, a single type of $G A B A_{A} R$ appears to be present in oligodendrocytes though its molecular nature remains elusive. (B) Recent evidence using gene expression and pharmacology shows that GABA ${ }_{A} R s$ in oligodendroglia are heterogeneous and may change in subunit composition during differentiation. Thus, at least two novel subtypes were identified: one formed by a combination of $\alpha 1$ or $\alpha 2, \beta 3$, and $\gamma 2$ subunits (Passlick et al., 2013) and another made up by $\alpha 3, \beta 2$ or $\beta 3$, and $\gamma 1$ or $\gamma 3$ subunits (Arellano et al., 2016). (C) In turn, studies using RT-PCR and/or immunohistochemistry conclude that SCs express high levels of $\alpha 2, \alpha 3, \beta 1, \beta 2$, and $\beta 3$, while $\alpha 1, \gamma 1$, and $\gamma 2$ levels are relatively low in these cells (Magnaghi et al., 2006).

have extrasynaptic $\mathrm{GABA}_{\mathrm{A}} \mathrm{Rs}$ mostly lacking the $\gamma 2$ subunit (Figure 1B).

Our studies of $\mathrm{GABA}_{\mathrm{A}} \mathrm{R}$ responses conducted in cultured immature OLs from the rat forebrain and mature OLs from the optic nerve showed that these cells are diazepam-sensitive, suggesting once more the presence of a $\gamma$ subunit (Arellano et al., 2016). This positive modulation by benzodiazepines was observed when using low GABA concentrations $\left(\leq \mathrm{EC}_{30}\right)$, which may explain the discrepancies with previous studies. Concerning the specific subtype of $\gamma$ subunit, two observations indicate that $\gamma 2$ may not contribute to oligodendroglial $\mathrm{GABA}_{\mathrm{A}}$ Rs: (1) $\mathrm{Zn}^{2+}$ blocks GABA responses; and (2) indiplon, a positive allosteric modulator acting on $\gamma 2$ subunit-containing receptors, does not modulate GABA currents. Therefore, these receptors likely contain either $\gamma 1$ or $\gamma_{3}$ subunit (Arellano et al., 2016).

Regarding $\beta$ subunits, potentiation of the GABA response by loreclezole suggests the presence of $\beta 2$ or $\beta 3$ subunits, since $\beta 1$ subunit-containing receptors are insensitive to this drug (Arellano et al., 2016). Finally, concerning $\alpha$ subunits, $\alpha 3$ is the most likely candidate because it forms receptors with low sensitivity to GABA (Karim et al., 2013), as it is the case of OLs $\left(\mathrm{EC}_{50}\right.$ between 70 and $\left.100 \mu \mathrm{M}\right)$.

Together, these pharmacological studies suggest that the composition of the $\mathrm{GABA}_{\mathrm{A}} \mathrm{R}$ expressed in rat-derived oligodendroglial cells is a combination of the $\alpha 3, \beta 2$ or $\beta 3$, and $\gamma 1$ or $\gamma 3$ subunits (Figure 1B). Also, we confirmed the expression of the $\alpha 3$ subunit by immunocytochemistry in cultured OLs (Arellano et al., 2016). These observations are supported by previous functional genomic analyses performed in OLs (Cahoy et al., 2008). Moreover, RNA sequencing (RNASeq) transcriptional analyses of purified NG2 cells obtained from P17 mice revealed that the $\alpha 3$ subunit is the most expressed $\alpha$-subtype, while among $\beta$ subunits, $\beta 3$ and $\beta 2$ are much more abundant than $\beta 1$. Lastly, $\gamma 1$ is expressed at much higher levels than $\gamma 2$ and $\gamma 3$ (Larson et al., 2016).

An important factor for the diversity of $G_{A B A} R s$ expressed and the subunits involved in their conformation will undoubtedly be the species. For example, regarding humans, a recent study of the $\mathrm{GABA}_{\mathrm{A}} \mathrm{R}$-subunit expression in OPCs isolated from the middle temporal gyrus of healthy adults-based on the single-nucleus RNA-Seq analysis by Hodge 
TABLE 1 | Pharmacological properties of neuronal and oligodendroglial GABA $A_{A}$ Rs.

\begin{tabular}{|c|c|c|c|}
\hline \multirow[b]{2}{*}{ Drug } & \multicolumn{2}{|c|}{ Neurons } & \multirow[b]{2}{*}{ Oligodendroglial cells } \\
\hline & Synaptic ( $\alpha x \beta x \gamma 2)$ & Extrasynaptic $(\alpha \times \beta \times \delta)$ & \\
\hline GABA & $\begin{array}{l}\text { Low } \mathrm{EC}_{50} 1-30 \mu \mathrm{M} \\
\text { (Gibbs et al., 1996; Baur and Sigel, } \\
\text { 2003; Mortensen et al., 2012) }\end{array}$ & $\begin{array}{l}\text { Low } \mathrm{EC}_{50} 0.5 \mathrm{nM}-10 \mu \mathrm{M} \\
\text { (Brown et al., 2002; Wallner et al., } \\
\text { 2003; Mortensen et al., 2012) }\end{array}$ & $\begin{array}{l}\text { High } \mathrm{EC}_{50} 70-100 \mu \mathrm{M} \\
\text { (Williamson et al., 1998; Arellano } \\
\text { et al., 2016) }\end{array}$ \\
\hline THIP & $\begin{array}{l}\text { No effect } \\
\text { (Mortensen et al., 2010) }\end{array}$ & $\begin{array}{l}+ \\
\text { (Brown et al., 2002; Meera et al., } \\
\text { 2011) }\end{array}$ & $\begin{array}{l}\text { No effect } \\
\text { (Arellano et al., 2016) }\end{array}$ \\
\hline$\beta-$-СВ & $\begin{array}{l}\text { - or No effect } \\
\text { (Peña et al., 1986; } \\
\text { Cisneros-Mejorado et al., 2020) }\end{array}$ & $\begin{array}{l}\text { No effect } \\
\text { (Jiménez-González et al., 2011) }\end{array}$ & $\begin{array}{l}+ \\
\text { (Arellano et al., 2016; } \\
\text { Cisneros-Mejorado et al., 2020) }\end{array}$ \\
\hline DMCM & $\begin{array}{l}- \\
\text { (Peña et al., 1986) }\end{array}$ & $\begin{array}{l}- \\
\text { (Brown et al., 2002) }\end{array}$ & $\begin{array}{l}\text { (von Blankenfeld et al., 1991; } \\
\text { Arellano et al., 2016) }\end{array}$ \\
\hline Indiplon & $\begin{array}{l}+ \\
\text { (Petroski et al., 2006) }\end{array}$ & $\begin{array}{l}\text { No effect } \\
\text { (Michelsen et al., 2007) }\end{array}$ & $\begin{array}{l}\text { No effect } \\
\text { (Arellano et al., 2016) }\end{array}$ \\
\hline Flunitrazepam & $\begin{array}{l}+ \\
\text { (Goodkin and Kapur, 2009) }\end{array}$ & $\begin{array}{l}\text { No effect } \\
\text { (Goodkin and Kapur, 2009) }\end{array}$ & $\begin{array}{l}+ \\
\text { (von Blankenfeld et al., 1991; } \\
\text { Arellano et al., 2016) }\end{array}$ \\
\hline Loreclezole & $\begin{array}{l}+^{\star} \\
\text { (Wingrove et al., 1994) }\end{array}$ & $\begin{array}{l}+^{\star} \\
\text { (Wingrove et al., 1994) }\end{array}$ & $\begin{array}{l}+ \\
\text { (Arellano et al., 2016) }\end{array}$ \\
\hline
\end{tabular}

(+) Potentiator/agonist; (-) Inhibitor; (*) $\beta 2$ or $\beta 3$ subunit required.

et al. (2019) - showed that OPCs from this brain area express high mRNA levels of $\alpha 3$, all $\beta$ subunits, $\gamma 2$ and, interestingly, the $\varepsilon$ subunit (Figure 2). These mRNAs, if translated and incorporated into functional receptors, would increase the variety of potential configurations and may have important functional and pharmacological consequences (Jones and Henderson, 2007; Bollan et al., 2008; Belujon et al., 2009).

\section{Schwann Cells}

$\mathrm{GABA}_{\mathrm{A}}$-type receptors are relevant to SC physiology (Magnaghi et al., 2001, 2006). However, their pharmacological and functional properties, as well as their molecular identity, are not clear. $\mathrm{GABA}_{\mathrm{A}} \mathrm{R}$ subunit composition in rat-derived cultured SCs includes $\alpha 2$ and $\alpha 3$, as well as the three $\beta$ subunits, while mRNAs of $\alpha 1$ and $\gamma 2$ subunits have been found at much lower levels (Magnaghi et al., 2006; Figure 1C). Moreover, the presence of $\alpha 2$, $\alpha 3$, and $\beta 3$ proteins were confirmed by immunocytochemistry. Alpha- 2 and $\beta 3$ subunits are also expressed in SC-like adult stem cells derived from bone marrow or adipose tissue, as their levels are upregulated following SC differentiation in vitro (Faroni et al., 2012). Also, $\mathrm{GABA}_{\mathrm{A}} \mathrm{R}$ stimulation with muscimol increases the proliferation rate of SCs, meaning that GABAergic signaling has an important role in these cells (Magnaghi et al., 2006). However, despite these important findings, there is still little knowledge about the specific composition of $\mathrm{GABA}_{\mathrm{A}} \mathrm{Rs}$ expressed in differentiated SCs.

\section{GABA $_{B}$ Receptors}

$\mathrm{GABA}_{B}$ Rs are G-protein coupled receptors (GPCRs) responsible for the slower and prolonged GABA-mediated inhibitory transmission. They were first described pharmacologically as bicuculline-insensitive metabotropic receptors that were activated by the GABA analog baclofen (Bowery and Hudson, 1979; Hill and Bowery, 1981). Functional $\mathrm{GABA}_{B} \mathrm{Rs}$ are heterodimers constituted by two receptor subunits, $\mathrm{GABA}_{\mathrm{B} 1}$ and $\mathrm{GABA}_{\mathrm{B} 2}$, that cooperate to perform signal activation (Kaupmann et al., 1998; Kuner et al., 1999). GABA ${ }_{B 1}$ is responsible for ligand binding, while $\mathrm{GABA}_{\mathrm{B} 2}$ contains binding sites for allosteric modulators (Galvez et al., 2001; Binet et al., 2004), couples with $\mathrm{G}_{\mathrm{i} / \mathrm{o}}$-protein, and is necessary for trafficking the heterodimer to the cell surface, where the receptor becomes active (Calver et al., 2000; Couve et al., 2000). Among the effector elements involved in $G_{A B A} R$ signaling pathways in neurons are voltage-gated $\mathrm{Ca}^{2+}$ channels (VGCC), inwardly-rectifying potassium channels (Kir) and adenylyl cyclase (AC; Bowery et al., 2002; Bettler et al., 2004; Figure 3). However, the specific coupling of $G_{A B A} A_{B}$ Rs to the molecular effector may differ depending on the cell type and region analyzed (Booker et al., 2018).

\section{Oligodendroglial Cells}

Myelinating cells express both subunits of $\mathrm{GABA}_{B} \mathrm{Rs}$, which are negatively-coupled to AC (Magnaghi et al., 2004; Luyt et al., 2007). However, their functional characteristics are not as well known as in the case of neurons. Regarding oligodendroglial cells, we recently confirmed by immunocytochemistry and RT-qPCR the expression of $G_{A B A}$ and $G_{1}$ ABA $A_{B 2}$ subunits in OPCs and OLs from the rat cerebral cortex and in OLs from the optic nerve (Serrano-Regal et al., 2020). We also performed calcium imaging assays and electrophysiological 


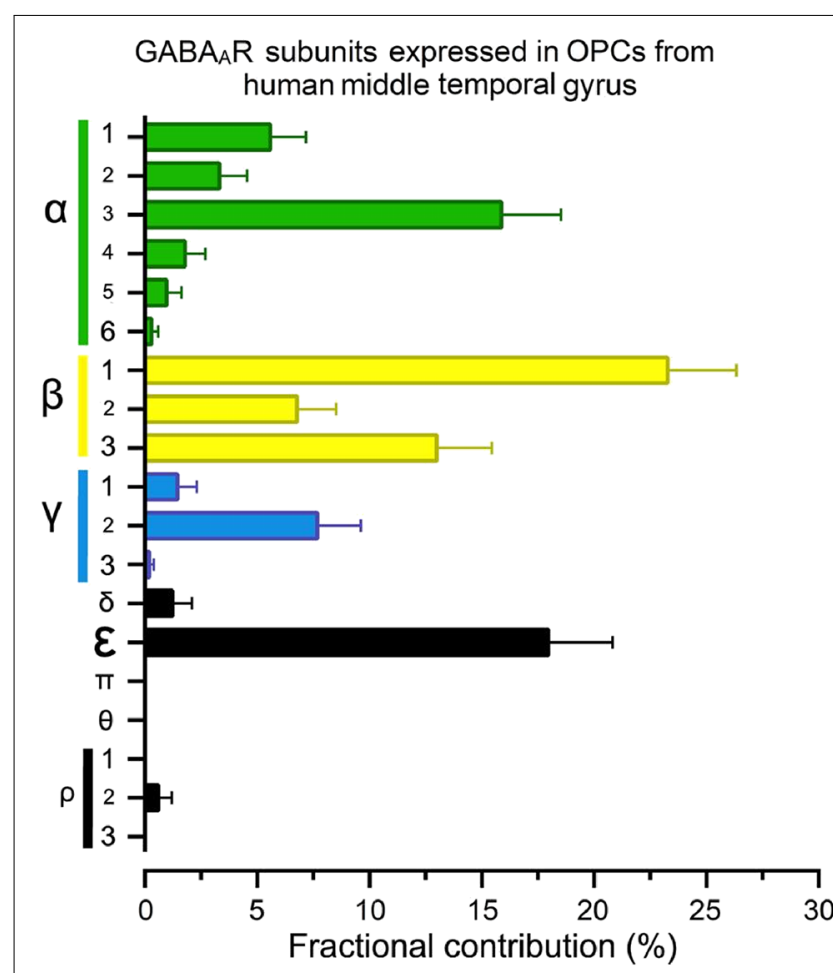

FIGURE 2 | The fractional contribution (FC) of $\mathrm{GABA}_{A} R$ subunits in human oligodendrocyte progenitor cells (OPCs). Normalized gene expression levels for all $19 \mathrm{GABA}_{A} \mathrm{R}$ subunits expressed as a percentage (mean \pm S.E.M.) of the total available pool of mRNA for $\mathrm{GABA}_{\mathrm{A}}$ Rs in OPCs (PDGFR $\alpha^{+}$cells) from human brains, estimated from publicly available datasets (Hodge et al., 2019; https://celltypes.brain-map.org/rnaseq). The single-nucleus analysis used normalized RNA-Seq datasets from the middle temporal gyrus isolated from six subjects with no known neuropsychiatry or neuropathological history (three males and three females; 35-66 years old). Gene expression level in each dataset was transformed into FC (Sequeira et al., 2019). FC is defined as the percentage of the expression level of each subunit gene (signaled in the "y" axis) to the sum of the 19 genes for GABA $A_{A}$ Rs subunits within each human/cell. Detailed demographic characteristics, as well as technical white papers for data processing and quality control, can be downloaded from the same site. Confirmatory analysis of OPC markers enrichment and lack of neuronal markers were performed for all datasets.

recordings in these cells and observed that baclofen does not modify their response to $\mathrm{KCl} 50 \mathrm{mM}$, calcium influx, and Kir currents. These results strongly suggest that $G_{A B A} R$ in oligodendroglial cells are not coupled to $\mathrm{Ca}^{2+}$ and Kir channels in the same manner as in other cell types (Serrano-Regal et al., 2020). Likewise, $\mathrm{GABA}_{\mathrm{B}}$ Rs from CA1 somatostatin interneurons, unlike pyramidal neurons, are not coupled to the canonical Kir3 signaling cascade (Booker et al., 2018), which suggests a functional diversity of downstream effectors depending on cell type and location, and warrants the need of exploring these features in OLs as well as in SCs.

Charles et al. (2003) did not find any colocalization of $\mathrm{GABA}_{\mathrm{B} 1}$ subunit and $\mathrm{MBP}$ expression in myelinating OLs in the white matter of the rat spinal cord and suggested that $\mathrm{GABA}_{\mathrm{B}} \mathrm{R}$ expression in developing OLs decreases during differentiation. Following this, Luyt et al. (2007) observed downregulation of the $\mathrm{GABA}_{\mathrm{B} 1}$ subunit in mature OLs from the mouse periventricular white matter, while the expression of $\mathrm{GABA}_{\mathrm{B} 2}$ remained constant. As they reported changes in $\mathrm{GABA}_{\mathrm{B} 1} / \mathrm{GABA}_{\mathrm{B} 2}$ ratios in mature OLs, they raised the possibility that one subunit alone or in combination with another protein could make $\mathrm{GABA}_{\mathrm{B}} \mathrm{R}$ functional in different cell types (Calver et al., 2000; Luyt et al., 2007). In contrast, our recent results show that cultured oligodendroglial cells from the rat forebrain and mature OLs from the optic nerve express GABA $\mathrm{B} 1$ and $\mathrm{GABA}_{\mathrm{B} 2}$ subunits at different stages of maturation, as well as mature OLs from the juvenile and adult rodent corpus callosum in vivo (Serrano-Regal et al., 2020). These discrepancies can be explained by the different regions analyzed, as $\mathrm{GABA}_{\mathrm{B} 1} / \mathrm{GABA}_{\mathrm{B} 2}$ expression exhibits important regional variations (Luyt et al., 2007). Since oligodendroglial cells are extremely diversified, the different cells targeted in these studies may correspond to distinct oligodendroglial and OPC subpopulations (Marques et al., 2016; Spitzer et al., 2019; Marisca et al., 2020).

\section{Schwann Cells}

SCs also express different isoforms of the $G_{A B A} R$, such as $-1 a$, -1b, -1c, and -2 (Magnaghi et al., 2004, 2006).

Downregulation of $\mathrm{GABA}_{B} \mathrm{R}$ expression occurs in preand non-myelinating SCs (Corell et al., 2015). Neurosteroids modulate the expression of $\mathrm{GABA}_{\mathrm{B}} \mathrm{R}$ subunits in cultured SCs and, as $G_{A B A} R$ is downregulated with age in the PNS, the GABA synthesized in the adult sciatic nerve acts through the ionotropic $\mathrm{GABA}_{\mathrm{A}} \mathrm{R}$, present both in neurons and SCs (Magnaghi et al., 2006). Interestingly, the conditional knockout of the $\mathrm{GABA}_{\mathrm{B} 1}$ subunit in SCs changes the expression of $\mathrm{GABA}_{\mathrm{A}} \mathrm{R}$ subunits $\alpha 3, \alpha 4, \beta 1$, and $\delta$ (Faroni et al., 2019), suggesting that $\mathrm{GABA}_{\mathrm{B}} \mathrm{Rs}$ in these cells regulate somehow the expression of $\mathrm{GABA}_{\mathrm{A}}$ Rs and/or their subunits.

Overall, more detailed analyses such as single-cell RNA-seq would help to better figure out the expression of $\mathrm{GABA}_{\mathrm{B} 1}$ and $\mathrm{GABA}_{\mathrm{B} 2}$ subunits along the oligodendroglial and SC lineages.

\section{POTENTIAL GABA SYNTHESIS AND RELEASE IN MYELINATING CELLS}

Although GABAergic neurons are the main source of GABA (especially in the CNS), GABA synthesis also occurs in glial cells (Seiler et al., 1979; Angulo et al., 2008; Héja et al., 2012). Two potential pathways for GABA synthesis have been described in brain-derived glial cells. GABA is mainly produced through the classical pathway as a result of glutamate decarboxylation by the glutamic acid decarboxylase (GAD) enzymes (Roberts and Frankel, 1950). In neurons, the two isoforms of GAD- $\mathrm{GAD}_{65}$ and $\mathrm{GAD}_{67}$-differ in their catalytic and kinetic properties and their subcellular distribution (Kaufman et al., 1991). Also, GABA can be synthesized from the monoacetylation of putrescine with the participation of the monoamine oxidase $\mathrm{B}\left(\mathrm{MAO}_{\mathrm{B}}\right)$ enzyme in the non-classical pathway (Seiler et al., 1973).

Consistent with an RNA-seq transcriptome and splicing database (Zhang et al., 2014), oligodendroglial cells express gad1, gad2, and maob mRNAs. GAD 67 mRNA (gad1) is greatly expressed by OPCs, although its levels decrease notably as they 


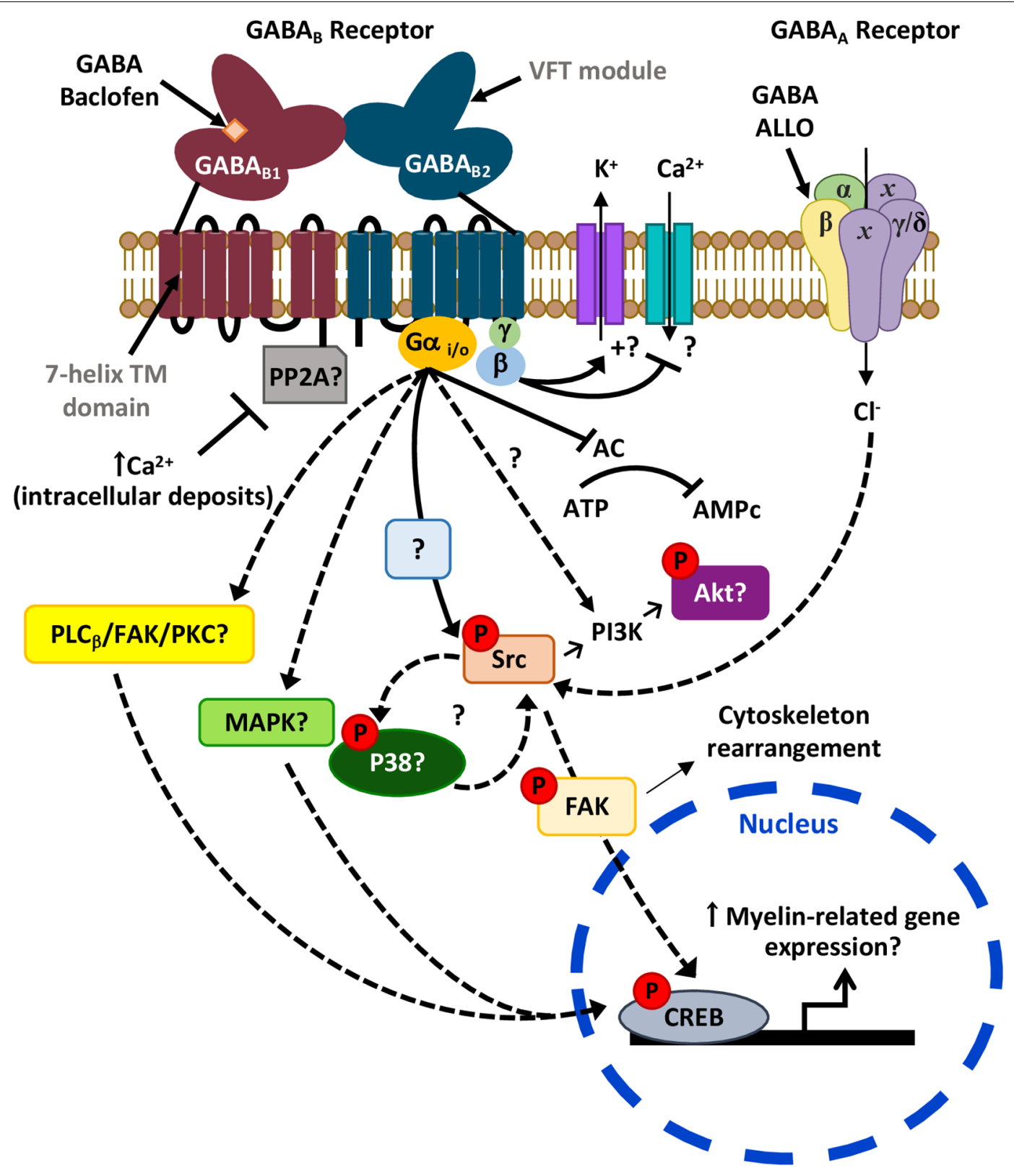

FIGURE 3 | Possible signaling pathways downstream GABARs leading to myelination. Activation of the Gi/o-linked GABA ${ }_{B}$ may reduce CREB phosphorylation as it is negatively coupled to adenylyl cyclase (AC; Luyt et al., 2007). Alternatively, it may also induce CREB phosphorylation possibly via activation of PLC $\beta / F A K / P K C$ or MAPK cascades, as observed in neurons (Carlezon et al., 2005; Zhang et al., 2015). Moreover, activation of GABA R leads to Src phosphorylation (Serrano-Regal et al., 2020) that could ultimately induce CREB activation. Phosphorylation of Src may also lead to Akt phosphorylation via PI3K as observed earlier (Barati et al., 2015), and contribute to a positive feedback loop with p38MAPK (Mugabe et al., 2010; Lin et al., 2015), which is involved in myelination (Fragoso et al., 2003, 2007). On the other hand, the $G_{A B A}$ subunit of $G A B A_{B} R$ might be sequestered by phosphatases like PP2A (as occurs in some neurons), a mechanism that blocks its activity and can be reverted by high intracellular $\mathrm{Ca}^{2+}$ levels (Li et al., 2020). Finally, the GABA $\mathrm{A}_{A} \mathrm{R}$ allosteric modulator ALLO regulates Schwann cell (SC) myelination via Src-FAK signaling, involving cytoskeleton reorganization (Melfi et al., 2017).

differentiate into mature myelinating OLs. However, gad2 is expressed to a lesser extent throughout the oligodendroglial lineage. Regarding maob, OPCs and myelinating OLs express higher levels than newly formed or immature OLs (Zhang et al., 2014). Accordingly, we confirmed the presence of $\mathrm{GAD}_{65 / 67}$ by immunocytochemistry and western blot in rat-derived cortical oligodendroglial cells at 1, 3, and 6 days in vitro (Serrano-Regal et al., 2020). Similarly, we verified the expression of the $\mathrm{MAO}_{\mathrm{B}}$ enzyme in these cells at the same time points. These results indicate that cultured oligodendroglial cells may synthesize GABA by the two alternative pathways mentioned above. Indeed, we found GABA immunostaining in cortical and optic-nerve 
derived oligodendroglial cells at different stages of maturation (Serrano-Regal et al., 2020). Possibly, GABA is synthesized by one pathway or another depending on the stage of maturation of the cells, as GABA may have different roles in OPCs vs. mature OLs.

$\mathrm{GAD}_{67}$ is present in SCs and its levels increase in the presence of the progesterone metabolite allopregnanolone (ALLO; Magnaghi et al., 2010). Moreover, Corell et al. (2015) demonstrated the presence of GABA and $\mathrm{GAD}_{65 / 67}$ in premyelinating and non-myelinating SCs. These findings show that SCs both produce and store GABA.

Together, these observations indicate that OLs and SCs synthesize and store GABA, which could be released by reversal operation of GABA transporters including GAT-1 and GAT-3, that are expressed by OLs (Fattorini et al., 2017; Serrano-Regal et al., 2020). Also, SCs are capable to take up ambient GABA at concentrations above $1 \mu \mathrm{M}$ (Brown et al., 1979), though the nature of the transporters involved is still unknown.

\section{GABA RECEPTORS IN OPC/SC PRECURSOR DIFFERENTIATION AND MYELINATION}

In the CNS, OPCs are the main (but not unique) source of remyelination, since they respond to white matter injury, migrate to the lesioned area and differentiate into mature OLs to produce new myelin sheaths (Franklin et al., 1997; Nait-Oumesmar et al., 1999; Hesp et al., 2015). Moreover, surviving mature OLs are also a source of remyelination (Duncan et al., 2018). SCs may also participate, although to a lesser extent, in restoring myelin in the CNS (Zawadzka et al., 2010; García-Díaz and Baron-Van Evercooren, 2020).

Differentiation of OPCs/SCs and myelination are exquisitely coordinated processes mediated by a deep dialogue between neuronal and glial cells that entail the participation of a variety of signals and intercellular communication systems, including ATP, glutamate or GABA neurotransmitter signaling (Li et al., 2013; Faroni et al., 2014; Salzer, 2015; Zonouzi et al., 2015; Arellano et al., 2016; Hamilton et al., 2017; Serrano-Regal et al., 2020), as well as neuronal activity (Wake et al., 2011; Gibson et al., 2014; Fannon et al., 2015). Specifically, GABAergic neurons establish direct synapses with OPCs throughout the CNS, indicating that this communication may control proliferation, migration, differentiation, the establishment of axonal contacts and their wrapping, OPC survival in the adult brain or myelin maintenance (Lin and Bergles, 2004; Kukley et al., 2008; VélezFort et al., 2010; Orduz et al., 2015; Zonouzi et al., 2015; Balia et al., 2017; Mount et al., 2019). However, the precise function of GABA in OPC differentiation and myelination remains controversial.

\section{GABA $_{A}$ Receptors}

Contrary to mature neurons, activation of $\mathrm{GABA}_{\mathrm{A}} \mathrm{Rs}$ in OPCs leads to depolarization and an increase in cytosolic $\mathrm{Ca}^{2+}$ levels (Kirchhoff and Kettenmann, 1992), resulting from $\mathrm{Ca}^{2+}$ influx through activated VGCC (Paez and Lyons, 2020). Thus, a rise in
$\mathrm{Ca}^{2+}$ in the cytosol may regulate OPC proliferation, migration and maturation and, consequently, OL (re)myelination (Cheli et al., 2016; Santiago-González et al., 2017; Baraban et al., 2018; Krasnow et al., 2018; Marisca et al., 2020).

As oligodendroglial cells constitute a highly dynamic and heterogeneous population, the expression of $\mathrm{GABA}_{\mathrm{A}} \mathrm{Rs}$ and their different subunits changes as these cells progress along their lineage, as occurs with the expression of certain ion-channels (Spitzer et al., 2019), and these changes can affect their intercellular relationship and differentiation. In line with this, we observed that oligodendroglial $\mathrm{GABA}_{\mathrm{A}} \mathrm{R}$ expression in vitro is dependent on the close interaction between axons and OLs, as OLs cultured alone lose GABA responses with differentiation (Arellano et al., 2016). Moreover, the presence of the $\gamma 2$ subunit, which is associated with a possible role in neuron-OPC synapse formation, decreases with age along with the density of GABAergic synaptic contacts in cortical NG2 cells of mature mice (Balia et al., 2015). Thus, NG2 cells may switch the expression of $\mathrm{GABA}_{\mathrm{A}} \mathrm{Rs}$ from synaptic (with $\gamma 2$ subunit) to extrasynaptic (without $\gamma 2$ subunit) during development (Vélez-Fort et al., 2010). Surprisingly, genetic inactivation of oligodendroglial $\gamma 2$ does not affect OPC proliferation and differentiation, while it causes progressive and specific depletion of the OPC pool that lacks $\gamma 2$-mediated synaptic activity without affecting the oligodendrocyte production (Balia et al., 2017). These observations indicate that GABAergic communication in cortical OPCs through $\gamma 2$-containing $\mathrm{GABA}_{\mathrm{A}} \mathrm{Rs}$ does not play a role in oligodendrogenesis but rather modulates OPC maintenance.

GABAergic signaling regulates OPC population and OPC differentiation and myelination in the cerebellar white matter in vivo (Zonouzi et al., 2015). In turn, hypoxia causes a strong downregulation of the GABAergic synaptic input from local interneurons to OPCs (NG2 cells) as well as an increase in the proliferation of these cells and a delay in their maturation, which limits myelination. These effects are mimicked in control animals when blocking $\mathrm{GABA}_{\mathrm{A}} \mathrm{Rs}$ with their antagonist bicuculline. However, they are reverted when applying tiagabine, a selective inhibitor of the GABA transporter GAT-1 that increases GABA availability in the extracellular space. Treatment with tiagabine results in a decrease of NG2 cell proliferation and an increase of myelinating OLs, reverting the hypomyelinating effect caused by perinatal hypoxia (Zonouzi et al., 2015). These findings strongly suggest that GABAergic signaling (either neuronal activitydependent or independent) influences OPC development and differentiation and, therefore, it may help to develop novel therapies to improve OPC differentiation into damaged brain areas.

GABAergic signaling through $\mathrm{GABA}_{\mathrm{A}}$ Rs may also be relevant for the stronger remyelination that occurs following focal demyelination in the corpus callosum of late pregnant rats compared to virgin and postpartum ones (Kalakh and Mouihate, 2019). This pregnancy-associated promyelinating effect was lost when either the $\mathrm{GABA}_{\mathrm{A}} \mathrm{R}$ was blocked or when $5 \alpha$-reductase, the rate-limiting enzyme for the endogenous $\mathrm{GABA}_{\mathrm{A}} \mathrm{R}$ activator ALLO, was inhibited (Kalakh and Mouihate, 2019). Moreover, 
N-butyl- $\beta$-carboline-3-carboxylate ( $\beta$-CCB), a selective drug activating preferentially oligodendroglial $\mathrm{GABA}_{\mathrm{A}} \mathrm{Rs}$, promotes remyelination in a model of gliotoxin-induced demyelination in the rat cerebellar caudal peduncle as assessed using magnetic resonance imaging (MRI) together with myelin staining (Cisneros-Mejorado et al., 2020). Together, these results strongly suggest that $\mathrm{GABA}_{\mathrm{A}} \mathrm{R}$-mediated signaling promotes myelination and remyelination in OLs either directly or indirectly. However, at odds with these data, activation of $\mathrm{GABA}_{\mathrm{A}}$ Rs by endogenous GABA in cortical organotypic cultures reduces the number of oligodendroglial cells and myelination whereas enlarges internode length, influencing the velocity of the nerve impulse propagation (Hamilton et al., 2017). These effects may be due to GABA released by glial cells. However, we could not assess this idea as gabazine treatment of OPC cultures had no significant effect on myelin protein production (Serrano-Regal et al., 2020).

Neurosteroid therapy is another pharmacological approach to modulate $\mathrm{GABA}_{\mathrm{A}} \mathrm{R}$ activity in the nervous system, as they act as allosteric modulators of these receptors in the nanomolar concentration range (Lambert et al., 2009). Indeed, progestin ALLO increases myelin basic protein (MBP) production in rat-derived cerebellar organotypic slices, an effect that requires $\mathrm{GABA}_{\mathrm{A}}$ Rs (Ghoumari et al., 2003). This observation points to these receptors as mediators of myelination. The effects of neurosteroids are of special interest in postnatal development, as they may help to prevent neurodevelopmental disorders associated with preterm birth (Shaw et al., 2019). ALLO, which is mainly synthesized in the placenta, has an important role during nervous system development. In premature neonates, ALLO concentration decreases abruptly and this decrease is associated, in part, with hypomyelination (Shaw et al., 2015). Consequently, experimental administration of the ALLO analog ganaxolone as replacement therapy in guinea pig-preterm neonates showed positive effects on myelination, through its interaction with $\mathrm{GABA}_{\mathrm{A}}$ Rs. Therefore, neurosteroid replacement could be a good therapeutic option to improve myelination in this condition (Shaw et al., 2019).

Neurosteroids may also enhance $\mathrm{GABA}_{\mathrm{A}} \mathrm{R}$ function in SCs. Thus, ALLO acting via $\mathrm{GABA}_{\mathrm{A}}$ receptor can influence peripheral myelin protein 22 (PMP22) synthesis (Magnaghi et al., 2006). Moreover, ALLO modulates SC morphology, motility, and myelination in SC/dorsal root ganglia neuron (DRG) co-cultures via the Src/focal adhesion kinase (FAK) pathway, a signaling cascade that involves $\mathrm{GABA}_{\mathrm{A}}$ Rs and relies on actin rearrangements (Melfi et al., 2017). Therefore, neurosteroids represent a promising molecular approach for the treatment of peripheric pathologies. Together, the studies discussed in this section connect $\mathrm{GABA}_{\mathrm{A}} \mathrm{R}$ signaling with $\mathrm{OPC} / \mathrm{SC}$ differentiation and/or myelination using pharmacological approaches. However, the results observed cannot be solely attributed to the action of $\mathrm{GABA}$ on $\mathrm{GABA}_{\mathrm{A}}$ Rs. Although pharmacology may be a good strategy to enhance OPC/SC differentiation and myelination in pathological conditions, potential side-effects must also be considered. To minimize them, it would be of great interest to use more specific drugs acting on myelinating cell $\mathrm{GABA}_{\mathrm{A}} \mathrm{Rs}$ and/or to use genetic approaches to specifically target the different $\mathrm{GABA}_{\mathrm{A}} \mathrm{R}$ subunits expressed in these cells.

\section{GABA $_{B}$ Receptors}

An early study suggests that $\mathrm{GABA}_{\mathrm{B}} \mathrm{Rs}$ may be relevant for OPC development as baclofen increases migration and proliferation in cultured OPCs derived from periventricular white matter (Luyt et al., 2007). However, more recent studies could not confirm those findings as baclofen did not change OPC proliferation or total OPC number in dissociated and organotypic cultures derived from the cortex (Hamilton et al., 2017; Serrano-Regal et al., 2020). This discrepancy could reflect the different brain areas studied. Thus, different subpopulations of OPCs may exist in white and gray matter that behave differently or have different responses to baclofen, as proposed by Luyt et al. (2007). In contrast, baclofen reduced cell proliferation of SC cultures (Magnaghi et al., 2004). However, in dissociated developing DRG primary cultures, in which SCs proliferate spontaneously in vitro, baclofen did not affect (Corell et al., 2015).

On the other hand, GABA and baclofen modulate OPC differentiation, as well as the myelination capacity of mature OLs cultured with DRG neurons, pointing out $\mathrm{GABA}_{\mathrm{B}} \mathrm{Rs}$ as relevant modulators of OL maturation and myelination (Serrano-Regal et al., 2020). Consistent with these observations, $\mathrm{GABA}_{B} \mathrm{Rs}$ also regulate SC differentiation both in the myelinating and non-myelinating phenotypes. Thus, forskolin-induced SC differentiation in vitro correlates with a redistribution of $G_{A B A}$ and $G_{B A B}$ 2 subunits of $G_{A B A}$ Rs. Indeed, in the cytoskeleton rearrangement that takes place during differentiation, $\mathrm{GABA}_{\mathrm{B}} \mathrm{Rs}$ colocalize with f-actin on the SC elongated processes (Procacci et al., 2013).

Apart from being essential for SC commitment to a non-myelinating phenotype during development, $\mathrm{GABA}_{\mathrm{B}} \mathrm{Rs}$ are key modulators of neuronal-SC interactions regarding myelination, as $\mathrm{GABA}_{\mathrm{B} 1}$ receptor total null mice showed altered levels of PMP22 and myelin protein zero (P0) as well as thinner myelin sheaths. These mice also presented fiber alterations, which causes changes in pain behavior, gait abnormalities, and motor coordination disturbances (Magnaghi et al., 2008). Together, these findings suggest a role for $G_{A B A}$ Rs in the control of SC myelination. Moreover, both $G_{A B A} R$ subunits in addition to GABA and $\mathrm{GAD}_{65 / 67}$ were found at the node of Ranvier in a sub-population of myelinated sensory fibers (Corell et al., 2015). Surprisingly, $G_{A B} A_{B} R$ expression is upregulated in SCs of injured nerves, which may be interpreted as an adaptive response for stimulating the neighboring axons to re-grow distally to the injury (Corell et al., 2015).

Finally, conditional deletion of the $\mathrm{GABA}_{\mathrm{B} 1}$ subunit in SCs altered their proliferation, migration, and myelination capacities, as well as reduced neurite length of co-cultured DRGs (Faroni et al., 2019). Furthermore, molecular and transcriptomic changes were also observed both in SCs and DRGs derived from mice lacking $\mathrm{GABA}_{\mathrm{B} 1}$ subunit in $\mathrm{SCs}\left(\mathrm{P} 0-\mathrm{GABA}-\mathrm{B1} 1^{\mathrm{f} / \mathrm{fl}}\right)$. Interestingly, the expression of some $\mathrm{GABA}_{\mathrm{A}} \mathrm{R}$ subunits by SCs and DRGs was also altered, indicating a possible role of $\mathrm{GABA}_{B} \mathrm{Rs}$ in regulating the expression of $\mathrm{GABA}_{\mathrm{A}} \mathrm{Rs}$ in these cells (Faroni et al., 2019). Similar studies using conditional deletion of $G A B A_{B} R$ 
subunits in oligodendroglia will help to understand the role of these receptors and their impact on myelination and pain and motor behavior.

\section{POSSIBLE SIGNALING PATHWAYS DOWNSTREAM GABARS RELATED TO MYELINATION}

Myelination, either by OLs or SCs, involves the participation of several intracellular signaling pathways. Indeed, some of those pathways are common in the CNS and PNS. For instance, binding of neuregulins (NRGs) to ErbB receptors activates a sequence of canonical intracellular pathways downstream from many receptor tyrosine kinases (RTKs), such as phosphatidylinositol-3-kinase (PI3K)/Akt/mammalian target of rapamycin (mTOR) or mitogen-activated protein kinases (MAPK; Newbern and Birchmeier, 2010).

Intracellular 3',5'-cyclic adenosine monophosphate (cAMP) induces cell differentiation and myelination requiring the participation of the cAMP response element-binding protein (CREB). CREB mediates the stimulation of MBP expression by cAMP in OLs (Afshari et al., 2001). Moreover, in mouse-derived cultured SCs, the combined action of cAMP/NRG1 increases the expression of myelin proteins Krox-20 and P0, through a mechanism that relies on the activity of transcription factors from the CREB family (Arthur-Farraj et al., 2011).

The Src family kinases (SFKs) are nonreceptor tyrosine kinases that integrate external signals from both integrin and growth factor receptors and transduce signals related to OL and SC development and myelination (Colognato et al., 2004; Melfi et al., 2017). In particular, signaling pathways downstream the Src-family member Fyn regulate morphological differentiation of OLs, the recruitment of cytoskeleton components, and local translation of MBP (see White and Krämer-Albers, 2014; Quintela-López et al., 2019). $\mathrm{GABA}_{\mathrm{B}} \mathrm{R}$ specific activation with baclofen induces Akt phosphorylation, which is dependent on PI3K and Src kinases, promoting chemotaxis and cytoskeletal rearrangement in rat basophilic leukemic cells (Barati et al., 2015). Accordingly, we found that Src-family kinases inhibition abrogates $\mathrm{GABA}_{\mathrm{B}} \mathrm{R}$-induced OL differentiation (Serrano-Regal et al., 2020). This observation corroborates the role of the Src family in OL differentiation through a mechanism dependent on $\mathrm{GABA}_{\mathrm{B}} \mathrm{R}$ activation (Figure 3 ).

$\mathrm{GABA}_{\mathrm{A}} \mathrm{Rs}$ are also linked to Src and FAK signaling. The modulation of SC development and myelination by the neurosteroid ALLO in SC/DRG co-cultures occurs via Src and FAK signaling activation, which depends on $\mathrm{GABA}_{\mathrm{A}}$ Rs and actin reorganization (Melfi et al., 2017). Besides, Src-family members can interact reciprocally with kinases from the MAPK family, like the serine/threonine-protein kinase p38 MAPK, as c-Src elicits p38 MAPK phosphorylation and the opposite (Mugabe et al., 2010; Lin et al., 2015; Wu et al., 2015). Therefore, it would be of great interest to investigate this kind of interactions in myelinating cells, as p38 MAPK is a key element in the initial steps of myelination in SCs (Fragoso et al., 2003), as well as in OL maturation and myelination since specific p38 inhibitors block in vitro myelination of DRGs by OLs (Fragoso et al., 2007).
Also, conditional knockout of p38 in oligodendroglial cells leads to defects in myelination early in development (Chung et al., 2015). At odds with those findings, deletion of $\mathrm{p} 38$ in the same mouse model increases remyelination after cuprizone-induced demyelination (Chung et al., 2015), while selective deletion of p38 $\alpha$ MAPK in OLs did not compromise myelination in a mouse model of periventricular leukomalacia (PVL; Chung et al., 2018). These conflicting pieces of evidence indicate that the precise role of p38 MAPK in SC/OL differentiation and myelination and its relation with GABARs remains to be elucidated (Figure 3).

Since $G_{A B A} R$ s couple negatively to $A C$ in OLs (Luyt et al., 2007), activation of CREB downstream these receptors is not expected due to decreased cAMP levels. However, other intracellular signaling cascades activated downstream G-protein coupled receptors, such as MAPK cascades, may phosphorylate CREB (see Carlezon et al., 2005). Thus, $\mathrm{GABA}_{B} \mathrm{R}$ stimulation in cultured mouse cerebellar granule neurons with baclofen activates CREB via PLC $\beta / F A K / P K C$ (Zhang et al., 2015). Further clarification of the link between $G_{A B A} R$ activation and CREB specifically in myelinating cells is a matter of ongoing study and could contribute to a better understanding of the signaling routes that control myelination and remyelination (Figure 3).

Finally, $\mathrm{GABA}_{\mathrm{B}} \mathrm{R}$ function may be modulated by its direct association to protein phosphatase $2 \mathrm{~A}$ (PP2A), as observed in GABAergic neurons from the rodent ventral tegmental area ( $\mathrm{Li}$ et al., 2020). Therefore, PP2A-GABA $A_{B}$ interaction results in an increase of $\mathrm{GABA}_{B} \mathrm{R}$ dephosphorylation and its subsequent internalization, an effect reverted with high intracellular $\mathrm{Ca}^{2+}$ levels. Again, it is worth exploring if these mechanisms also occur in myelinating cells and whether they are relevant to myelin pathology (Figure 3).

\section{DISCUSSION}

GABA is among the signals that drive OLs and SCs to axon interactions. The fact that GABA acts mainly on two different types of receptors-ionotropic $\mathrm{GABA}_{\mathrm{A}} \mathrm{Rs}$ and metabotropic $\mathrm{GABA}_{B} \mathrm{Rs}$ - makes it difficult to understand the role of this neurotransmitter in myelinating cell physiology. Moreover, OLs and SCs are highly dynamic cell lineages with different stages of maturation.

While the molecular composition of both GABARs and their mechanisms of action are well described in neurons, their properties in myelinating glial cells remain elusive. Native $\mathrm{GABA}_{\mathrm{A}} \mathrm{Rs}$ are composed of multiple subunit combinations with diverse pharmacology, both of which vary regionally, adding a huge heterogeneity to their properties and functions. This diversity is also reflected somehow in $\mathrm{GABA}_{\mathrm{A}} \mathrm{Rs}$ in OLs and SCs. Thus, SCs express extra-synaptic subunits (in particular the $\delta$ subunit, which is key for neurosteroid affinity), while OLs express subunits commonly found at postsynaptic densities, meaning that $\mathrm{GABA}_{\mathrm{A}} \mathrm{Rs}$ of OLs and SCs have different subunit composition and, consequently, different pharmacological profiles and functional behaviors (Faroni et al., 2019). Also, there is a switch in the expression of synaptic to extrasynaptic $\mathrm{GABA}_{\mathrm{A}}$ Rs as OPCs progress in the lineage (VélezFort et al., 2010; Balia et al., 2017). 


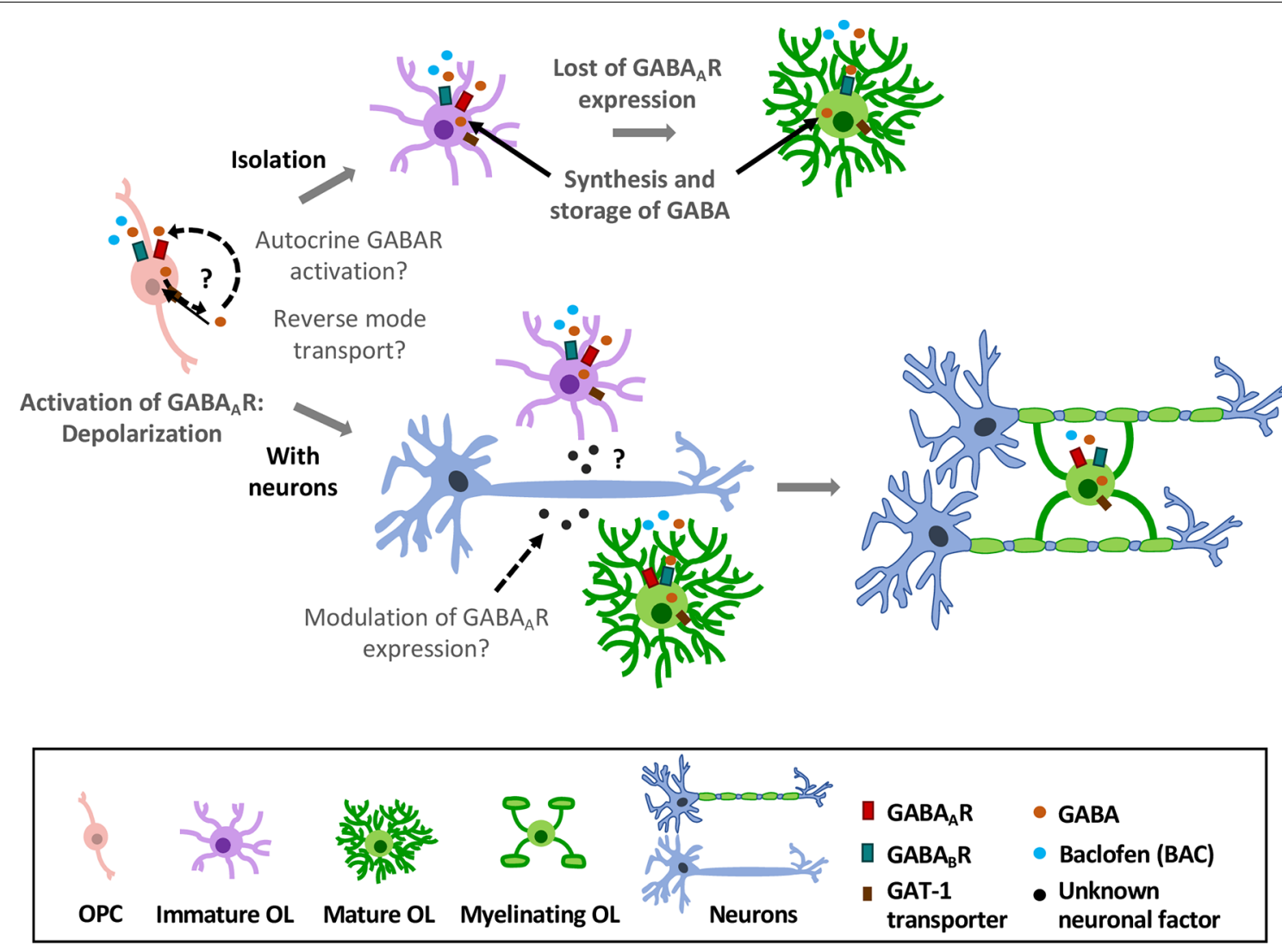

FIGURE 4 | Effects of GABAergic signaling in oligodendroglial differentiation and myelination. OPCs express GABA $A_{A}$ and GABA $A_{B} R s$. Activation of GABA $A_{A}$ Rs causes depolarization in these cells (Kirchhoff and Kettenmann, 1992; Baraban et al., 2018). In absence of axons (top), they lose GABA $R_{A}$ expression as they differentiate into mature OLs (Berger et al., 1992; Arellano et al., 2016); however, expression of GABA $A_{B} R s$ is largely stable over time (Serrano-Regal et al., 2020). In the presence of axons (low), GABA $R$ R expression is modulated by neurons, as OPCs maintain their expression towards the myelinating stage (Arellano et al., 2016). Moreover, oligodendroglial cells express GAT-1 transporter and synthesize GABA, which may be released by reverse GAT-1 operation and activate GABA receptors (GABARs) in an autocrine manner. Exogenous GABA or baclofen promotes oligodendroglial differentiation and myelination in vitro (Serrano-Regal et al., 2020).

In oligodendroglial cells, $\mathrm{GABA}_{\mathrm{A}} \mathrm{R}$ expression goes down as they mature and acquire a myelinating phenotype (Berger et al., 1992; Arellano et al., 2016). In contrast, $\mathrm{GABA}_{\mathrm{B}} \mathrm{R}$ expression is quite stable at all stages (Serrano-Regal et al., 2020). Sustained $\mathrm{GABA}_{\mathrm{A}} \mathrm{R}$ expression in oligodendroglial cells depends on the presence of axons, though the mechanisms driving $\mathrm{GABA}_{\mathrm{A}} \mathrm{R}$ stabilization remain still unknown. Thus, it is likely that molecules released from neurons in an activityindependent manner may drive $\mathrm{GABA}_{\mathrm{A}} \mathrm{R}$ expression (Arellano et al., 2016; Hamilton et al., 2017; Figure 4).

Also, OLs and SCs can synthesize and store GABA, and to take it up from the extracellular fluid through specific GABA transporters (Fattorini et al., 2017). It is therefore conceivable that these cells may release GABA by mechanisms including reverse functioning of the transporters, as observed in other glial cell types (Barakat and Bordey, 2002). Early experiments demonstrated that cultured satellite glial cells from DRG can release $\left[{ }^{3} \mathrm{H}\right] \mathrm{GABA}$ in response to a depolarizing stimulus (Minchin and Iversen, 1974). Thus, GABA released by myelinating cells might act in a paracrine or autocrine way (as suggested by Magnaghi, 2007) to, ultimately, modulate their differentiation and/or their myelination capacity (Figure 4). Interestingly, this mechanism operates for instance in polysialylated forms of neural cell-adhesion molecule (PSA-NCAM) progenitor cells in the CNS, which eventually differentiate into glial cells. Thus, autocrine/paracrine loops involving neurosteroids and GABA signaling in these progenitors modulate their proliferation and differentiation (Gago et al., 2004). Synthesis of neurosteroids occurs in SCs (Chan et al., 2000), and may stimulate GABA synthesis in these cells via a rapid protein kinase A (PKA)-dependent autocrine loop (Magnaghi et al., 2010). In this way, neurosteroids provide the specific ligand for $\mathrm{GABA}_{\mathrm{A}} \mathrm{R}$ activation (Magnaghi et al., 2010). As neurosteroids are involved in promoting SC differentiation and myelination acting through $\mathrm{GABA}_{\mathrm{A}} \mathrm{Rs}$, a possible paracrine/autocrine mechanism could underlie these processes.

$\mathrm{GABA}_{\mathrm{A}}$ and $\mathrm{GABA}_{\mathrm{B}}$ receptors may exert opposite roles on myelinating cells, as proposed for SCs in pathological conditions (Faroni and Magnaghi, 2011). Both central and peripheral myelinating cells express $\mathrm{GABA}_{\mathrm{A}}$ and $\mathrm{GABA}_{\mathrm{B}}$ receptors, however, this expression depends on the presence 
of surrounding axons and, as occurs with other receptors and transporters, may vary along the lineage or even depending on the nervous system area (Marques et al., 2016; Spitzer et al., 2019). Thus, depending on the developmental stage of these cells and the GABAR involved, the neurotransmitter GABA may play different physiological functions. Moreover, GABAergic signaling could potentially regulate specific subgroups of cells from the OL/SC lineages in different ways, either actionpotential dependently or independently. Thus, it appears that in OPCs GABA acts mostly through $\mathrm{GABA}_{\mathrm{A}}$ Rs to carry out some important functions at the progenitor level (as regulation of the population size, OPC maintenance, axon-glia recognition, differentiation or myelination initiation; Zonouzi et al., 2015; Arellano et al., 2016; Balia et al., 2017; Hamilton et al., 2017; Marisca et al., 2020).

Finally, $\mathrm{GABA}_{\mathrm{B}} \mathrm{Rs}$ may contribute to myelin maintenance (Figure 4). In this regard, GABARs may parallel somehow the various functions played by glutamate receptors, as AMPARs are crucial for the early stages of remyelination while NMDARs are relevant for myelin maintenance and to fuel axonal function (Lundgaard et al., 2013; Gautier et al., 2015; Saab et al., 2016).

In sum, understanding the contribution of the GABAergic signaling to OL and SC physiology may be critical to find therapeutic tools to improve remyelination in demyelinating diseases. Meanwhile, it is necessary to clarify in detail the role of GABA in OL and SC differentiation and myelination,

\section{REFERENCES}

Afshari, F. S., Chu, A. K., and Sato-Bigbee, C. (2001). Effect of cyclic AMP on the expression of myelin basic protein species and myelin proteolipidprotein in committed oligodendrocytes: differential involvement of the transcription factor CREB. J. Neurosci. Res. 66, 37-45. doi: 10.1002/ jnr.1195

Allen, N. J., and Lyons, D. A. (2018). Glia as architects of central nervous system formation and function. Science 362, 181-185. doi: 10.1126/science.aat0473

Angulo, M. C., Le Meur, K., Kozlov, A. S., Charpak, S., and Audinat, E. (2008). GABA, a forgotten gliotransmitter. Prog. Neurobiol. 86, 297-303. doi: 10.1016/j. pneurobio.2008.08.002

Arellano, R. O., Sánchez-Gómez, M. V., Alberdi, E., Canedo-Antelo, M., Chara, J. C., Palomino, A., et al. (2016). Axon-to-glia interaction regulates $\mathrm{GABA}_{\mathrm{A}}$ receptor expression in oligodendrocytes. Mol. Pharmacol. 89, 63-74. doi: $10.1124 / \mathrm{mol} .115 .100594$

Arthur-Farraj, P., Wanek, K., Hantke, J., Davis, C. M., Jayakar, A., Parkinson, D. B., et al. (2011). Mouse Schwann cells need both NRG1 and cyclic AMP to myelinate. Glia 59, 720-733. doi: 10.1002/glia.21144

Balia, M., Benamer, N., and Angulo, M. C. (2017). A specific GABAergic synapse onto oligodendrocyte precursors does not regulate cortical oligodendrogenesis. Glia 65, 1821-1832. doi: 10.1002/glia.23197

Balia, M., Vélez-Fort, M., Passlick, S., Schäfer, C., Audinat, E., Steinhäuser, C., et al. (2015). Postnatal down-regulation of the $\mathrm{GABA}_{\mathrm{A}}$ receptor $\gamma 2$ subunit in neocortical NG2 cells accompanies synaptic-to-extrasynaptic switch in the GABAergic transmission mode. Cereb. Cortex 25, 1114-1123. doi: 10.1093/cercor/bht309

Baraban, M., Koudelka, S., and Lyons, D. A. (2018). $\mathrm{Ca}^{2+}$ activity signatures of myelin sheath formation and growth in vivo. Nat. Neurosci. 21, 19-23. doi: 10.1038/s41593-017-0040-x

Barakat, L., and Bordey, A. (2002). GAT-1 and reversible GABA transport in Bergmann glia in slices. J. Neurophysiol. 88, 1407-1419. doi: 10.1152/jn.2002. 88.3.1407

Barati, M. T., Lukenbill, J., Wu, R., Rane, M. J., and Klein, J. B. (2015). Cytoskeletal rearrangement and Src and PI-3K-dependent Akt activation control GABA $\mathrm{GA}_{B}$ - and the mechanisms that mediate these responses. To that aim, it will be important to specifically target $\mathrm{GABA}_{\mathrm{A}}$ Rs and $\mathrm{GABA}_{B}$ Rs either at the progenitor stage or the more mature stages of the myelinating cells. Drugs preferentially acting on GABARs in OLs and SCs will certainly help to successfully tackle these tasks.

\section{AUTHOR CONTRIBUTIONS}

MS-R and RA wrote the manuscript, designed its content, and prepared the figures and table. $\mathrm{LB}-\mathrm{C}, \mathrm{RO}$, and $\mathrm{AL}$ wrote the manuscript and prepared the figures and table. EG wrote the manuscript. CM and MS-G wrote the manuscript and designed its content.

\section{FUNDING}

This work was supported by CIBERNED (CB06/05/0076; $\mathrm{CM}$ ) and by grants from the Ministry of Economy and Competitiveness, Government of Spain (SAF2016-75292-R and PID2019-109724RB-I00; CM), Basque Government (IT120319; CM), CONACYT-México (No. 252121; RA), PAPIITUNAM-México (IN203519; RA) and NIH (R21AG053740 and R21MH113177; AL). MS-R was hired thanks to the Gangoiti Foundation (Bilbao). LB-C and RO hold fellowships from Basque Government and CONACYT-México, respectively.

mediated chemotaxis. Cell. Signal. 27, 1178-1185. doi: 10.1016/j.cellsig.2015. 02.022

Barnard, E. A., Skolnick, P., Olsen, R. W., Mohler, H., Sieghart, W., Biggio, G., et al. (1998). International Union of Pharmacology. XV. Subtypes of gammaaminobutyric acid A receptors: classification on the basis of subunit structure and receptor function. Pharmacol. Rev. 50, 291-313.

Baur, R., and Sigel, E. (2003). On high- and low-affinity agonist sites in $\mathrm{GABA}_{\mathrm{A}}$ receptors. J. Neurochem. 87, 325-332. doi: 10.1046/j.1471-4159.2003.01982.x

Belujon, P., Baufreton, J., Grandoso, L., Boué-Grabot, E., Batten, T. F., Ugedo, L., et al. (2009). Inhibitory transmission in locus coeruleus neurons expressing $\mathrm{GABA}_{\mathrm{A}}$ receptor epsilon subunit has a number of unique properties. J. Neurophysiol. 102, 2312-2325. doi: 10.1152/jn.00227.2009

Ben-Ari, Y. (2002). Excitatory actions of gaba during development: the nature of the nurture. Nat. Rev. Neurosci. 3, 728-739. doi: 10.1038/nrn920

Berger, T., Walz, W., Schnitzer, J., and Kettenmann, H. (1992). GABA-and glutamate-activated currents in glial cells of the mouse corpus callosum slice. J. Neurosci. Res. 31, 21-27. doi: 10.1002/jnr.490310104

Bettler, B., Kaupmann, K., Mosbacher, J., and Gassmann, M. (2004). Molecular structure and physiological functions of $\mathrm{GABA}_{B}$ receptors. Physiol. Rev. 84, 835-867. doi: 10.1152/physrev.00036.2003

Binet, V., Brajon, C., Le Corre, L., Acher, F., Pin, J. P., and Prézeau, L. (2004). The heptahelical domain of $\mathrm{GABA}_{B 2}$ is activated directly by CGP7930, a positive allosteric modulator of the $\mathrm{GABA}_{B}$ receptor. J. Biol. Chem. 279, 29085-29091. doi: 10.1074/jbc.m400930200

Bollan, K. A., Baur, R., Hales, T. G., Sigel, E., and Connolly, C. N. (2008). The promiscuous role of the epsilon subunit in $\mathrm{GABA}_{\mathrm{A}}$ receptor biogenesis. Mol. Cell. Neurosci. 37, 610-621. doi: 10.1016/j.mcn.2007.12.011

Booker, S. A., Loreth, D., Gee, A. L., Watanabe, M., Kind, P. C., Wyllie, D. J. A., et al. (2018). Postsynaptic $\mathrm{GABA}_{B}$ Rs inhibit L-type calcium channels and abolish long-term potentiation in hippocampal somatostatin interneurons. Cell. Rep. 22, 36-43. doi: 10.1016/j.celrep.2017.12.021

Bowery, N. G., Bettler, B., Froestl, W., Gallagher, J. P., Marshall, F., Raiteri, M., et al. (2002). International Union of Pharmacology. XXXIII. Mammalian gamma-aminobutyric $\mathrm{Acid}_{B}$ receptors: structure and function. Pharmacol. Rev. 54, 247-264. doi: 10.1124/pr.54.2.247 
Bowery, N. G., and Hudson, A. L. (1979). $\gamma$-aminobutyric acid reduces the evoked release of $[3 \mathrm{H}]$-noradrenaline from sympathetic nerve therminals [proceedings]. Br. J. Pharmacol. 66:108P.

Bronstein, J. M., Hales, T. G., Tyndale, R. F., and Charles, A. C. (1998). A conditionally immortalized glial cell line that expresses mature myelin proteins and functional GABA A receptors. J. Neurochem. 70, 483-491. doi: 10.1046/j. 1471-4159.1998.70020483.x

Brown, D. A., Adams, P. R., Higgins, A. J., and Marsh, S. (1979). Distribution of gaba-receptors and gaba-carriers in the mammalian nervous system. J. Physiol. 75, 667-671.

Brown, N., Kerby, J., Bonnert, T. P., Whiting, P. J., and Wafford, K. A. (2002). Pharmacological characterization of a novel cell line expressing human $\alpha_{4} \beta_{3} \delta$ GABA $_{A}$ receptors. Br. J. Pharmacol. 136, 965-974. doi: 10.1038/sj.bjp.0704796

Cahoy, J. D., Emery, B., Kaushal, A., Foo, L. C., Zamanian, J. L., Christopherson, K. S., et al. (2008). A transcriptome database for astrocytes, neurons and oligodendrocytes: a new resource for understanding brain development and function. J. Neurosci. 28, 264-278. doi: 10.1523/JNEUROSCI. 4178-07.2008

Calver, A. R., Medhurst, A. D., Robbins, M. J., Charles, K. J., Evans, M. L., Harrison, D. C., et al. (2000). The expression of $\mathrm{GABA}_{B 1}$ and $\mathrm{GABA}_{B 2}$ receptor subunits in the CNS differs from that in peripheral tissues. Neuroscience 100, 155-170. doi: 10.1016/s0306-4522(00)00262-1

Carlezon, W. A. Jr., Duman, R. S., and Nestler, E. J. (2005). The many faces of CREB. Trends Neurosci. 28, 436-445. doi: 10.1016/j.tins.2005.06.005

Carver, C. M., Chuang, S., and Reddy, D. S. (2016). Zinc selectively blocks neurosteroid-sensitive extrasynaptic $\delta \mathrm{GABA} A$ receptors in the hippocampus. J. Neurosci. 36, 8070-8077. doi: 10.1523/jneurosci.3393-15.2016

Chan, J. R., Rodriguez-Waitkus, P. M., Ng, B. K., Liang, P., and Glaser, M. (2000). Progesterone synthesized by Schwann cells during myelin formation regulates neuronal gene expression. Mol. Biol. Cell. 11, 2283-2295. doi: 10.1091/mbc.11. 7.2283

Charles, K. J., Deuchars, J., Davies, C. H., and Pangalos, M. N. (2003). $\mathrm{GABA}_{B}$ receptor subunit expression in glia. Mol. Cell. Neurosci. 24, 214-223. doi: 10.1016/s1044-7431(03)00162-3

Cheli, V. T., Sántiago-González, D. A., Namgyal-Lama, T., Spreuer, V., Handley, V., Murphy, G. G., et al. (2016). Conditional deletion of the L-type calcium channel Cav1.2 in oligodendrocyte progenitor cells affects postnatal myelination in mice. J. Neurosci. 36, 10853-10869. doi: 10.1523/jneurosci.177016.2016

Chung, S. H., Biswas, S., Selvaraj, V., Liu, X. B., Sohn, J., Jiang, P., et al. (2015). The p38 $\alpha$ mitogen-activated protein kinase is a key regulator of myelination and remyelination in the CNS. Cell Death Dis. 6:e1748. doi: 10.1038/cddis.2015.119

Chung, S. H., Biswas, S., Sohn, J., Jiang, P., Dehghan, S., Marzban, H., et al. (2018). The p38 $\alpha$ MAPK deletion in oligodendroglia does not attentuate myelination defects in a mouse model of periventricular leukomalacia. Neuroscience 386, 175-181. doi: 10.1016/j.neuroscience.2018.06.037

Cisneros-Mejorado, A. J., Garay, E., Ortiz-Retana, J., Concha, L., Moctezuma, J. P., Romero, S., et al. (2020). Demyelination-remyelination of the rat caudal cerebellar peduncle evaluated with magnetic resonance imaging. Neuroscience 439, 255-267. doi: 10.1016/j.neuroscience.2019.06.042

Colognato, H., Ramachandrappa, S., Olsen, I. M., and ffrench-Constant, C. (2004). Integrins direct Src family kinases to regulate distinct phases of oligodendrocyte development. J. Cell Biol. 167, 365-375. doi: 10.1083/jcb.200 404076

Corell, M., Wicher, G., Radomska, K. J., Daglikoca, E. D., Godskesen, R. E., Fredriksson, R., et al. (2015). GABA and its B-receptor are present at the node of Ranvier in a small population of sensory fibers, implicating a role in myelination. J. Neurosci. Res. 93, 285-295. doi: 10.1002/jnr.23489

Couve, A., Moss, S. J., and Pangalos, M. N. (2000). GABA $B$ receptors: a new paradigm in G protein signaling. Mol. Cell. Neurosci. 16, 296-312. doi: 10.1006/mcne.2000.0908

Dawson, M. R., Polito, A., Levine, J. M., and Reynolds, R. (2003). NG2-expressing glial progenitor cells: an abundant and widespread population of cycling cells in the adult rat CNS. Mol. Cell. Neurosci. 24, 476-488. doi: 10.1016/s10447431(03)00210-0

Doyon, N., Vinay, L., Prescott, S. A., and De Koninck, Y. (2016). Chloride regulation: a dynamic equilibrium crucial for synaptic inhibition. Neuron 89, 1157-1172. doi: 10.1016/j.neuron.2016.02.030
Duncan, I. D., Radcliff, A. B., Heidari, M., Kidd, G., August, B. K., and Wierenga, L. A. (2018). The adult oligodendrocyte can participate in remyelination. Proc. Natl. Acad. Sci. U S A 115, E11807-E11816. doi: 10.1073/pnas.1808064115

Fannon, J., Tarmier, W., and Fulton, D. (2015). Neuronal activity and AMPA-type glutamate receptor activation regulates the morphological development of oligodendrocyte precursor cells. Glia 63, 1021-1035. doi: 10.1002/glia.22799

Faroni, A., and Magnaghi, V. (2011). The neurosteroid allopregnanolone modulates specific functions in central al peripheral glial cells. Front. Endocrinol. 2:103. doi: 10.3389/fendo.2011.00103

Faroni, A., Melfi, S., Castelnovo, L. F., Bonalume, V., Colleoni, D., Magni, P., et al. (2019). GABA-B1 receptor-null Schwann cells exhibit compromised in vitro myelination. Mol. Neurobiol. 56, 1461-1474. doi: 10.1007/s12035-018-1158-x

Faroni, A., Smith, R. J., Procacci, P., Castelnovo, L. F., Puccianti, E., Reid, A. J., et al. (2014). Purinergic signaling mediated by P2X7 receptors controls myelination in sciatic nerves. J. Neurosci. Res. 92, 1259-1269. doi: 10.1002/jnr.23417

Faroni, A., Terenghi, G., and Magnaghi, V. (2012). Expression of functional $\gamma$ aminobutyric acid type A receptors in Schwann-like adult stem cells. J. Mol Neurosci. 47, 619-630. doi: 10.1007/s12031-011-9698-9

Fattorini, G., Melone, M., Sánchez-Gómez, M. V., Arellano, R. O., Bassi, S., Matute, C., et al. (2017). GAT-1 mediated GABA uptake in rat oligodendrocytes. Glia 65, 514-522. doi: 10.1002/glia.23108

Fragoso, G., Haines, J. D., Robertson, J., Pedraza, L., Mushynski, W. E., and Almazan, G. (2007). p38 mitogen-activated protein kinase is required for central nervous system myelination. Glia 55, 1531-1541. doi: 10.1002/glia. 20567

Fragoso, G., Robertson, J., Athlan, E., Tam, E., Almazan, G., and Mushynski, W. E. (2003). Inhibition of p38 mitogen-activated protein kinase interferes with cell shape changes and gene expression associated with Schwann cell myelination. Exp. Neurol. 183, 34-46. doi: 10.1016/s0014-4886(03)00101-8

Franklin, R. J., Gilson, J. M., and Blakemore, W. F. (1997). Local recruitment of remyelinating cells in the repair of demyelination in the central nervous system. J. Neurosci. Res. 50, 337-344. doi: 10.1002/(sici)10974547(19971015)50:2<337::aid-jnr21>3.0.co;2-3

Gago, N., El-Etr, M., Sananès, N., Cadepond, F., Samuel, D., Avellana-Adalid, V., et al. (2004). 3alpha,5alpha-Tetrahydroprogesterone (allopregnanolone) and gamma-aminobutyric acid: autocrine/paracrine interactions in the control of neonatal PSA-NCAM+ progenitor proliferation. J. Neurosci. Res. 78, 770-783. doi: 10.1002/jnr.20348

Galvez, T., Duthey, B., Kniazeff, J., Blahos, J., Rovelli, G., Bettler, B., et al. (2001). Allosteric interactions between GB1 and GB2 subunits are required for optimal $\mathrm{GABA}_{B}$ receptor function. EMBO J. 20, 2152-2159. doi: 10.1093/emboj/ 20.9.2152

García-Díaz, B., and Baron-Van Evercooren, A. (2020). Schwann cells: recuers of central demyelination. Glia doi: 10.1002/glia.23788 [Epub ahead of print].

Gautier, H. O., Evans, K. A., Volbracht, K., James, R., Sitnikov, S., Lundgaard, I., et al. (2015). Neuronal activity regulates remyelination via glutamate signalling to oligodendrocyte protenitors. Nat. Commun. 6:8518. doi: $10.1038 /$ ncomms 9518

Ghoumari, A. M., Ibanez, C., El-Etr, M., Leclerc, P., Eychenne, B., O’Malley, B. W., et al. (2003). Progesterone and its metabolites increase myelin basic protein expression in organotypic slice cultures of rat cerebellum. J. Neurochem. 86, 848-859. doi: 10.1046/j.1471-4159.2003.01881.x

Gibbs, J. W., Zhang, Y. F., Kao, C. Q., Holloway, K. L., Oh, K. S., and Coulter, D. A. (1996). Characterization of $\mathrm{GABA}_{\mathrm{A}}$ receptor function in human temporal cortical neurons. J. Neurophysiol. 75, 1458-1471. doi: 10.1152/jn.1996. 75.4.1458

Gibson, E. M., Purger, D., Mount, C. W., Goldstein, A. K., Lin, G. L., Wood, L. S., et al. (2014). Neuronal activity promotes oligodendrogenesis and adaptive myelination in the mammalian brain. Science 344:1252304. doi: $10.1126 /$ science. 1252304

Goodkin, H. P., and Kapur, J. (2009). The impact of diazepam's discovery on the treatment and understanding of status epilepticus. Epilepsia 50, 2011-2018. doi: 10.1111/j.1528-1167.2009.02257.x

Hamilton, N. B., Clarke, L. E., Arancibia-Carcamo, I. L., Kougioumtzidou, E., Matthey, M., Karadottir, R., et al. (2017). Endogenous GABA controls oligodendrocyte lineage cell number, myelination and CNS internode length. Glia 65, 309-321. doi: 10.1002/glia.23093 
Héja, L., Nyitrai, G., Kékesi, O., Dobolyi, A., Szabó, P., Fiáth, R., et al. (2012). Astrocytes convert network excitation to tonic inhibition of neurons. BMC Biol. 10:26. doi: 10.1186/1741-7007-10-26

Hesp, Z. C., Goldstein, E. A., Miranda, C. J., Kaspar, B. K., McTigue, D. M., Kaspar, B. K., et al. (2015). Chronic oligodendrogenesis and remyelination after spinal cord injury in mice and rats. J. Neurosci. 35, 1274-1290. doi: 10.1523/jneurosci.1414-15.2015

Hill, D. R., and Bowery, N. G. (1981). ${ }^{3} \mathrm{H}-$ Baclofen and ${ }^{3} \mathrm{H}-\mathrm{GABA}$ bind to bicuculline-insensitive $\mathrm{GABA}_{B}$ sites in rat brain. Nature 290, 149-152. doi: 10.1038/290149a0

Hodge, R. D., Bakken, T. E., Miller, J. A., Smith, K. A., Barkan, E. R., Graybuck, L. T., et al. (2019). Conserved cell types with divergent features in human versus mouse cortex. Nature 573, 61-68. doi: 10.1038/s41586-0191506-7

Hosie, A. M., Dunne, E. L., Harvey, R. J., and Smart, T. G. (2003). Zincmediated inhibition of $\mathrm{GABA}_{\mathrm{A}}$ receptors: discrete binding sites underlie subtype specificity. Nat. Neurosci. 6, 362-369. doi: 10.1038/nn1030

Jessen, K. R., and Mirsky, R. (2005). The origin and development of glial cells in peripheral nerves. Nat. Rev. Neurosci. 6, 671-682. doi: 10.1038/nrn1746

Jessen, K. R., and Mirsky, R. (2019). The success and failure of the Schwann cell response to nerve injury. Front. Cell. Neurosci. 13:33. doi: 10.3389/fncel.2019. 00033

Jiménez-González, C., Pirttimaki, T., Cope, D. W., and Parri, H. R. (2011). Nonneuronal, slow GABA signalling in the ventrobasal thalamus targets $\delta$-subunitcontaining $\mathrm{GABA}_{\mathrm{A}}$ receptors. Eur. J. Neurosci. 33, 1471-1482. doi: 10.1111/j. 1460-9568.2011.07645.x

Jones, B. L., and Henderson, L. P. (2007). Trafficking and potential assembly patterns of epsilon-containing $\mathrm{GABA}_{\mathrm{A}}$ receptors. J. Neurochem. 103, 1258-1271. doi: 10.1111/j.1471-4159.2007.04833.x

Kalakh, S., and Mouihate, A. (2019). Enhanced remyelination during late pregnancy: involvement of the GABAergic system. Sci. Rep. 9:7728. doi: 10.1038/s41598-019-44050-4

Karim, N., Wellendorph, P., Absalom, N., Johnston, G. A., Hanrahan, J. R., and Chebib, M. (2013). Potency of GABA at human recombinant $\mathrm{GABA}_{\mathrm{A}}$ receptors expressed in Xenopus oocytes: a mini review. Amino Acids 44, 1139-1149. doi: 10.1007/s00726-012-1456-y

Kaufman, D. L., Houser, C. R., and Tobin, A. J. (1991). Two forms of the gamma-aminobutyric acid synthetic enzyme glutamate decarboxylase have distinct intraneuronal distributions and cofactor interactions. J. Neurochem. 56, 720-723. doi: 10.1111/j.1471-4159.1991.tb08211.x

Kaupmann, K., Malitschek, B., Schuler, V., Heid, J., Froestl, W., Beck, P., et al. (1998). $\mathrm{GABA}_{B}$-receptor subtypes assemble into functional heteromeric complexes. Nature 396, 683-687. doi: 10.1038/25360

Kidd, G. J., Ohno, N., and Trapp, B. D. (2013). Biology of Schwann cells. Handb. Clin. Neurol. 115, 55-79. doi: 10.1016/B978-0-444-52902-2.00005-9

Kirchhoff, F., and Kettenmann, H. (1992). GABA triggers a $\left[\mathrm{Ca}^{2+}\right]_{i}$ increase in murine precursor cells of the oligodendrocyte lineage. Eur. J. Neurosci. 4, 1049-1058. doi: 10.1111/j.1460-9568.1992.tb00131.x

Krasnow, A. M., Ford, M. C., Valdivia, L. E., Wilson, S. W., and Attwell, D. (2018). Regulation of developing myelin sheath elongation by oligodendrocyte calcium transients in vivo. Nat. Neurosci. 21, 24-30. doi: 10.1038/s41593-017-0031-y

Kukley, M., Kiladze, M., Tognatta, R., Hans, M., Swandulla, D., Schramm, J., et al. (2008). Glial cells are born with synapses. FASEB J. 22, 2957-2969. doi: 10.1096/fj.07-090985

Kuner, R., Köhr, G., Grünewald, S., Eisenhardt, G., Bach, A., and Kornau, H. C. (1999). Role of the heteromer formation in $\mathrm{GABA}_{B}$ receptor function. Science 283, 74-77. doi: 10.1126/science.283.5398.74

Lambert, J. J., Cooper, M. A., Simmons, R. D., Weir, C. J., and Belelli, D. (2009). Neurosteroids: endogenous allosteric modulators of $\mathrm{GABA}_{\mathrm{A}}$ receptors. Psychoneuroendocrinology 34, S48-S58. doi: 10.1016/j.psyneuen.2009.08.009

Larson, V. A., Zhang, Y., and Bergles, D. E. (2016). Electrophysiological properties of $\mathrm{NG}^{+}$cells: matching physiological studies with gene expression profiles. Brain Res. 1638, 138-160. doi: 10.1016/j.brainres.2015.09.010

Levitan, E. S., Schofieldh, P. R., Burt, D. R., Rhee, L. M., Wisden, W., Kohler, M., et al. (1988). Structural and functional basis for $\mathrm{GABA}_{\mathrm{A}}$ receptor heterogeneity. Nature 335, 76-79. doi: 10.1038/335076a0

Li, C., Xiao, L., Liu, X., Yang, W., Shen, W., Hu, C., et al. (2013). A functional role of NMDA receptor in regulating the differentiation of oligodendrocyte precursor cells and remyelination. Glia 61, 732-749. doi: 10.1002/glia. 22469

Li, X., Terunuma, M., Deeb, T. G., Wiseman, S., Pangalos, M. N., Nairn, A. C., et al. (2020). Direct interaction of PP2A phosphatase with $\mathrm{GABA}_{B}$ receptors alters functional signaling. J. Neurosci. 40, 2808-2816. doi: 10.1523/JNEUROSCI. 2654-19.2020

Lin, S. C., and Bergles, D. E. (2004). Synaptic signaling between GABAergic interneurons and oligodendrocyte precursor cells in the hippocampus. Nat. Neurosci. 7, 24-32. doi: 10.1038/nn1162

Lin, C. C., Lee, I. T., Hsu, C. H., Hsu, C. K., Chi, P. L., Hsiao, L. D., et al. (2015). Sphingosine-1-phosphate mediates ICAM-1-dependent monocyte adhesion through p38 MAPK and p42/p44 MAPK-dependent Akt activation. PLoS One 10:e0118473. doi: 10.1371/journal.pone.0118473

Lundgaard, I., Luzhynskaya, A., Stockley, J. H., Wang, Z., Evans, K. A., Swire, M., et al. (2013). Neuregulin and BDNF induce a switch to NMDA receptor-dependent myelination by oligodendrocytes. PLoS Biol. 11:e1001743. doi: 10.1371/journal.pbio.1001743

Luyt, K., Slade, T. P., Dorward, J. J., Durant, C. F., Wu, Y., Shigemoto, R., et al. (2007). Developing oligodendrocytes express functional $\mathrm{GABA}_{B}$ receptors that stimulate cell proliferation and migration. J. Neurochem. 100, 822-840. doi: 10.1111/j.1471-4159.2006.04255.x

Magnaghi, V. (2007). GABA and neuroactive steroid interactions in glia: new roles for old players? Curr. Neuropharmacol. 5, 47-64. doi: 10.2174/157015907780077132

Magnaghi, V., Ballabio, M., Camozzi, F., Colleoni, M., Consoli, A., Gassmann, M., et al. (2008). Altered peripheral myelination in mice lacking $\mathrm{GABA}_{B}$ receptors. Mol. Cell. Neurosci. 37, 599-609. doi: 10.1016/j.mcn.2007.12.009

Magnaghi, V., Ballabio, M., Cavarretta, I. T., Froestl, W., Lambert, J. J., Zucchi, I., et al. (2004). GABA $B$ receptors in Schwann cells influence proliferation and myelin protein expression. Eur. J. Neurosci. 19, 2641-2649. doi: 10.1111/j.0953816x.2004.03368.x

Magnaghi, V., Ballabio, M., Consoli, A., Lambert, J. J., Roglio, I., and Melcangi, R. C. (2006). GABA receptor-mediated effects in the peripheral nervous system: a cross-interaction with neuroactive steroids. J. Mol. Neurosci. 28, 89-102. doi: 10.1385/jmn:28:1:89

Magnaghi, V., Cavarretta, I., Galbiati, M., Martini, L., and Melcangi, R. C. (2001). Neuroactive steroids and peripheral myelin proteins. Brain Res. Rev. 37, 360-371. doi: 10.1016/s0165-0173(01)00140-0

Magnaghi, V., Parducz, A., Frasca, A., Ballabio, M., Procacci, P., Racagni, G., et al. (2010). GABA synthesis in Schwann cells is induced by the neuroactive steroid allopregnanolone. J. Neurochem. 112, 980-990. doi: 10.1111/j.1471-4159.2009. 06512.x

Marisca, R., Hoche, T., Agirre, E., Jane Hoodless, L., Barkey, W., Auer, F., et al. (2020). Functionally distinct subgroups of oligodendrocyte precursor cells integrate neural activity and execute myelin formation. Nat. Neurosci. 23, 363-374. doi: 10.1038/s41593-019-0581-2

Marques, S., Zeisel, A., Codeluppi, S., van Bruggen, D., Mendanha Falcão, A., Xiao, L., et al. (2016). Oligodendrocyte heterogeneity in the mouse juvenile and adult central nervous system. Science 352, 1326-1329. doi: 10.1126/science. aaf6463

Meera, P., Wallner, M., and Otis, T. S. (2011). Molecular basis for the high THIP/gaboxadol sensitivity of extrasynaptic GABA A receptors. J. Neurophysiol. 106, 2057-2064. doi: 10.1152/jn.00450.2011

Melfi, S., Montt Guevara, M. M., Bonalume, V., Ruscica, M., Colciago, A., Simoncini, T., et al. (2017). Src and phosphor-FAK kinases are activated by allopregnanolone promoting Schwann cell motility, morphology and myelination. J. Neurochem. 141, 165-178. doi: 10.1111/jnc.13951

Michelsen, S., Sánchez, C., and Ebert, B. (2007). Lack of generalisation between the $\mathrm{GABA}_{\mathrm{A}}$ receptor agonist, gaboxadol and allosteric modulators of the benzodiazepine binding site in the rat drug discrimination procedure. Psychopharmacology 193, 151-157. doi: 10.1007/s00213-007-0750-y

Minchin, M. C., and Iversen, L. L. (1974). Release of (3H)gamma-aminobutyric acid from glial cells in rat dorsal root ganglia. J. Neurochem. 23, 533-540. doi: 10.1111/j.1471-4159.1974.tb06056.x

Mitew, S., Gobius, I., Fenlon, L. R., McDougall, S. J., Hawkes, D., Xing, Y. L., et al. (2018). Pharmacogenetic stimulation of neuronal activity increases myelination in an axon-specific manner. Nat. Commun. 9:306. doi: 10.3410/f.732542465. 793542118 
Mortensen, M., Ebert, B., Wafford, K., and Smart, T. G. (2010). Distinct activities of GABA agonists at synaptic- and extrasynaptic-type $\mathrm{GABA}_{\mathrm{A}}$ receptors. J. Physiol. 588, 1251-1268. doi: 10.1113/jphysiol.2009.182444

Mortensen, M., Patel, B., and Smart, T. G. (2012). GABA potency at $\mathrm{GABA}_{\mathrm{A}}$ receptors found in synaptic and extrasynaptic zones. Front. Cell. Neurosci. 6:1. doi: 10.3389/fncel.2012.00001

Mount, C. W., Yalçın, B., Cunliffe-Koehler, K., Sundaresh, S., and Monje, M. (2019). Monosynaptic tracing maps brain-wide afferent oligodendrocyte precursor cell connectivity. Elife 8:e49291. doi: 10.7554/eLife.49291

Mugabe, B. E., Yaghini, F. A., Song, C. Y., Buharalioglu, C. K., Waters, C. M., and Malik, K. U. (2010). Angiotensin II-induced migration of vascular smooth muscle cells is mediated by p38 mitogen-activated protein kinase-activated c-Src through spleen tyrosine kinase and epidermal growth factor receptor transactivation. J. Pharmacol. Exp. Ther. 332, 116-124. doi: 10.1124/jpet.109. 157552

Nait-Oumesmar, B., Decker, L., Lachapelle, F., Avellana-Adalid, V., Bachelin, C., and Baron-Van Evercooren, A. (1999). Progenitor cells of the adult mouse subventricular zone proliferate, migrate and differentiate into oligodendrocytes after demyelination. Eur. J. Neurosci. 11, 4357-4366. doi: 10.1046/j.1460-9568. 1999.00873.x

Nave, K. A., and Trapp, B. D. (2008). Axon-glial signaling and the glial support of axon function. Annu. Rev. Neurosci. 31, 535-561. doi: 10.1146/annurev.neuro. 30.051606.094309

Newbern, J., and Birchmeier, C. (2010). Nrg1/ErbB signaling networks in Schwann cell development and myelination. Semin. Cell. Dev. Biol. 21, 922-928. doi: 10.1016/j.semcdb.2010.08.008

Olsen, R. W., and Sieghart, W. (2008). International Union of Pharmacology. LXX. Subtypes of gamma-aminobutyric Acid $_{\mathrm{A}}$ receptors: classification on the basis of subunit composition, pharmacology and function. Update. Pharmacol. Rev. 60, 243-260. doi: 10.1124/pr.108.00505

Orduz, D., Maldonado, P. P., Balia, M., Vélez-Fort, M., de Sars, V., Yanagawa, Y., et al. (2015). Interneurons and oligodendrocyte progenitors form a structured synaptic network in the developing neocortex. Elife 4:e06953. doi: 10.7554/eLife.06953.021

Paez, P. M., and Lyons, D. (2020). Calcium signaling in the oligodendrocyte lineage: regulators and consequences. Annu. Rev. Neurosci. 43, 163-186. doi: 10.1146/annurev-neuro-100719-093305

Passlick, S., Grauer, M., Schafer, C., Jabs, R., Seifert, G., and Steinhauser, C. (2013). Expression of the 2-subunit distinguishes synaptic and extrasynaptic $\mathrm{GABA}_{\mathrm{A}}$ receptors in NG2 cells of the hippocampus. J. Neurosci. 33, 12030-12040. doi: 10.1523/JNEUROSCI.5562-12.2013

Peña, C., Medina, J. H., Novas, M. L., Paladini, A. C., and De Robertis, E. (1986). Isolation and identification in bovine cerebral cortex of n-butyl $\beta$-carboline-3carboxylate, a potent benzodiazepine binding inhibitor. Proc. Natl. Acad. Sci. U S A 83, 4952-4956. doi: 10.1073/pnas.83.13.4952

Petroski, R. E., Pomeroy, J. E., Das, R., Bowman, H., Yang, W., Chen, A. P., et al. (2006). Indiplon is a high-affinity positive allosteric modulator with selectivity for alphal subunit-containing $\mathrm{GABA}_{\mathrm{A}}$ receptors. J. Pharmacol. Exp. Ther. 317, 369-377. doi: 10.1124/jpet.105.096701

Philips, T., and Rothstein, J. D. (2017). Oligodendroglia: metabolic supporters of neurons. J. Clin. Invest. 127, 3271-3280. doi: 10.1172/JCI90610

Procacci, P., Ballabio, M., Castelnovo, L. F., Mantovani, C., and Magnaghi, V. (2013). GABA-B receptors in the PNS have a role in Schwann cells differentiation? Front. Cell. Neurosci. 6:68. doi: 10.3389/fncel.2012. 00068

Quintela-López, T., Ortiz-Sanz, C., Serrano-Regal, M. P., Gaminde-Blasco, A., Valero, J., Baleriola, J., et al. (2019). A $\beta$ oligomers promote oligodendrocyte differentiation and maturation via integrin $\beta 1$ and Fyn kinase signaling. Cell Death Dis. 10:445. doi: 10.1038/s41419-019-1636-8

Roberts, E., and Frankel, S. (1950). $\gamma$-aminobutyric acid in brain: its formation from glutamic acid. J. Biol. Chem. 187, 55-63.

Saab, A. S., Tzvetavona, I. D., Trevisiol, A., Baltan, S., Dibaj, P., Kusch, K., et al. (2016). Oligodendroglial NMDA receptors regulate glucose import and axonal energy metabolism. Neuron 91, 119-132. doi: 10.1016/j.neuron.2016.05.016

Salzer, J. (2015). Schwann cell myelination. Cold Spring Harb. Perspect. Biol. 7:a020529. doi: 10.1101/cshperspect.a020529

Santiago-González, D. A., Cheli, V. T., Zamora, N. N., Lama, T. N., Spreuer, V., Murphy, G. G., et al. (2017). Conditional deletion of the L-type calcium channel
Cav1.2 in NG2-positive cells impairs remyelination in mice. J. Neurosci. 37, 10038-10051. doi: 10.1523/JNEUROSCI.1787-17.2017

Seeburg, P. H., Wisden, W., Verdoorn, T. A., Pritchett, D. B., Werner, P., Herb, A., et al. (1990). The $\mathrm{GABA}_{\mathrm{A}}$ receptor family: molecular and functional diversity. Cold Spring Harb. Symp. Quant. Biol. 55, 29-40. doi: 10.1101/sqb.1990.055. 01.006

Seiler, N., al-Therib, M. J., and Kataola, K. (1973). Formation of GABA from putrescine in the brain of fish (Salmo irideus Gibb.). J. Neurochem. 20, 699-708. doi: 10.1111/j.1471-4159.1973.tb00030.x

Seiler, N., Schmidt-Glenewinkel, T., and Sarhan, S. (1979). On the formation of gamma-aminobutyric acid from putrescine in brain. J. Biochem. 86, 277-279. doi: 10.1093/oxfordjournals.jbchem.a132515

Sequeira, A., Shen, K., Gottlieb, A., and Limon, A. (2019). Human brain transcriptome analysis finds region- and subject-specific expression signatures of GABA ${ }_{A}$ R subunits. Commun. Biol. 2:153. doi: 10.1038/s42003-019-0413-7

Serrano-Regal, M. P., Luengas-Escuza, I., Bayón-Cordero, L., Ibarra-Aizpurua, N., Alberdi, E., Pérez-Samartín, A., et al. (2020). Oligodendrocyte differentiation and myelination is potentiated via $\mathrm{GABA}_{B}$ receptor activation. Neuroscience 439, 163-180. doi: 10.1016/j.neuroscience.2019.07.014

Shaw, J. C., Berry, M. J., Dyson, R. M., Crombie, G. K., Hirst, J. J., and Palliser, H. K. (2019). Reduced neurosteroid exposure following preterm birth and its' contribution to neurological impairment: a novel avenue for preventative therapies. Front. Physiol. 10:599. doi: 10.3389/fphys.2019. 00599

Shaw, J. C., Dyson, R. M., Palliser, H. K., Gray, C., Berry, M. J., and Hirst, J. J. (2019). Neurosteroid replacement therapy using the allopregnanoloneanalogue ganaxolone following preterm birth in male guinea pigs. Pediatr. Res. 85, 86-96. doi: 10.1038/s41390-018-0185-7

Shaw, J. C., Palliser, H. K., Walker, D. W., and Hirst, J. J. (2015). Preterm birth affects $\mathrm{GABA}_{\mathrm{A}}$ receptor subunit mRNA levels during the foetal-toneonatal transition in guinea pigs. J. Dev. Orig. Health Dis. 6, 250-260. doi: $10.1017 /$ S2040174415000069

Sieghart, W., and Savić, M. M. (2018). International Union of Basic and Clinical Pharmacology. CVI: $\mathrm{GABA}_{\mathrm{A}}$ receptor subtype- and function-selective ligands: key issues in translation to humans. Pharmacol. Rev. 70, 836-878. doi: 10.1124/pr.117.014449

Spitzer, S. O., Sitnikov, S., Kamen, Y., Evans, K. A., Kronenberg-Versteeg, D., Dietmann, S., et al. (2019). Oligodendrocyte progenitor cells become regionally diverse and heterogeneous with age. Neuron 101, 459-471. doi: 10.1016/j. neuron.2018.12.020

Vélez-Fort, M., Audinat, E., and Angulo, M. C. (2012). Central role of GABA in neuron-glia interactions. Neuroscientist 18, 237-250. doi: $10.1177 / 1073858411403317$

Vélez-Fort, M., Maldonado, P. P., Butt, A. M., Audinat, E., and Angulo, M. C. (2010). Postnatal switch from synaptic to extrasynaptic transmission between interneurons and NG2 cells. J. Neurosci. 30, 6921-6929. doi: 10.1523/JNEUROSCI.0238-10.2010

Vogt, K. (2015). "Diversity in GABAergic signaling," in Diversity and Functions of GABA Receptors: a Tribute to Hanns Möhler, Part B, ed. U. Rudolph (Waltham and San Diego, USA; London and Oxford, UK: Elsevier Inc.), 203-222.

von Blankenfeld, G., Trotter, J., and Kettenmann, H. (1991). Expression and developmental regulation of a $\mathrm{GABA}_{\mathrm{A}}$ receptor in cultured murine cells of the oligodendrocyte lineage. Eur. J. Neurosci. 3, 310-316. doi: 111/j.1460-9568. 1991.tb00817.x

Wake, H., Lee, P. R., and Fields, R. D. (2011). Control of local protein synthesis and initial events in myelination by action potentials. Science 333, 1647-1651. doi: $10.1126 /$ science. 1206998

Waldvogel, H. J., and Faull, R. L. M. (2015). "The diversity of $\mathrm{GABA}_{\mathrm{A}}$ receptor subunit distribution in the normal and Huntington's disease human brain ${ }^{1}$,' in Diversity and Functions of GABA Receptors: a Tribute to Hanns Möhler, Part $B$, ed. U. Rudolph (London and Oxford, UK: Elsevier Inc.), 223-264.

Wallner, M., Hanchar, H. J., and Olsen, R. W. (2003). Ethanol enhances alpha 4 beta 3 delta and alpha 6 beta 3 delta gamma-aminobutyric acid type A receptors at low concentrations known to affect humans. Proc. Natl. Acad. Sci. U S A 100, 15218-15223. doi: 10.1073/pnas.2435171100

Walters, R. J., Hadley, S. H., Morris, K. D. W., and Amin, J. (2000). Benzodiazepines act on $\mathrm{GABA}_{\mathrm{A}}$ receptors via two distinct and separable mechanisms. Nat. Neurosci. 3, 1274-1281. doi: 10.1038/81800 
White, R., and Krämer-Albers, E. M. (2014). Axon-glia interaction and membrane traffic in myelin formation. Front. Cell. Neurosci. 7:284. doi: 10.3389/fncel.2013. 00284

Williamson, A. V., Mellor, J. R., Grant, A. L., and Randall, A. D. (1998). Properties of $\mathrm{GABA}_{\mathrm{A}}$ receptors in cultured rat oligodendrocyte progenitor cells. Neuropharmacology 37, 859-873. doi: 10.1016/s0028-3908(98) 00016-1

Wingrove, P. B., Wafford, K. A., Bain, C., and Whiting, P. J. (1994). The modulatory action of loreclezole at the gamma-aminobutyric acid type A receptor is determined by a single amino acid in the beta 2 and beta 3 subunit. Proc. Natl. Acad. Sci. U S A 91, 4569-4573. doi: 10.1073/pnas.91.10.4569

Wu, H., Shi, Y., Deng, X., Su, Y., Du, C., Wei, J., et al. (2015). Inhibition of cSrc/p38 MAPK pathway ameliorates renal tubular epithelial cells apoptosis in db/db mice. Mol. Cell. Endocrinol. 417, 27-35. doi: 10.1016/j.mce.2015.09.008

Zawadzka, M., Rivers, L. E., Fancy, S. P., Zhao, C., Tripathi, R., Jamen, F., et al. (2010). CNS-resident glial progenitors/stem cells produce Schwann cells as well as oligodendrocytes during repair of CNS demyelination. Cell Stem Cell 6, 578-590. doi: 10.1016/j.stem.2010.04.002

Zhang, Y., Chen, K., Sloan, S. A., Bennett, M. L., Scholze, A. R., O’ Keeffe, S., et al. (2014). An RNA-sequencing transcriptome and splicing database of glia, neurons and vascular cells of the cerebral cortex. J. Neurosci. 34, 11929-11947. doi: 10.1523/JNEUROSCI.1860-14.2014

Zhang, W., Xu, C., Tu, H., Wang, Y., Sun, Q., Hu, P., et al. (2015). GABA $B$ receptor upregulates Fragile $\mathrm{X}$ mental retardation protein expression in neurons. Sci. Rep. 5:10468. doi: 10.1038/srep10468

Zonouzi, M., Scafidi, J., Li, P., McEllin, B., Edwards, J., Dupree, J. L., et al. (2015). GABAergic regulation of cerebellar NG2 cell development is altered in perinatal white matter injury. Nat. Neurosci. 18, 674-682. doi: 10.1038/nn.3990

Conflict of Interest: The authors declare that the research was conducted in the absence of any commercial or financial relationships that could be construed as a potential conflict of interest.

Copyright (c) 2020 Serrano-Regal, Bayón-Cordero, Ordaz, Garay, Limon, Arellano, Matute and Sánchez-Gómez. This is an open-access article distributed under the terms of the Creative Commons Attribution License (CC BY). The use, distribution or reproduction in other forums is permitted, provided the original author(s) and the copyright owner(s) are credited and that the original publication in this journal is cited, in accordance with accepted academic practice. No use, distribution or reproduction is permitted which does not comply with these terms. 